\title{
Article \\ Protection of Cholinergic Neurons against Zinc Toxicity by Glial Cells in Thiamine-Deficient Media
}

\author{
Sylwia Gul-Hinc ${ }^{1}$, Anna Michno ${ }^{1}$, Marlena Zyśk ${ }^{2}$, Andrzej Szutowicz ${ }^{1}$, Agnieszka Jankowska-Kulawy ${ }^{1}$ \\ and Anna Ronowska $1, * \mathbb{D}$
}

1 Department of Laboratory Medicine, Medical University of Gdansk, 80-210 Gdansk, Poland; sylwia.gul-hinc@gumed.edu.pl (S.G.-H.); anna.michno@gumed.edu.pl (A.M.); agnieszka.jankowska-kulawy@gumed.edu.pl (A.S.); marlena.zysk@gumed.edu.pl (A.J.-K.)

2 Department of Molecular Medicine, Medical University of Gdansk, 80-210 Gdansk, Poland; andrzej.szutowicz@gumed.edu.pl

* Correspondence: anna.ronowska@gumed.edu.pl; Tel.: +48-58-349-27-70

Citation: Gul-Hinc, S.; Michno, A.; Zyśk, M.; Szutowicz, A.;

Jankowska-Kulawy, A.; Ronowska, A. Protection of Cholinergic Neurons against Zinc Toxicity by Glial Cells in Thiamine-Deficient Media. Int. J. Mol. Sci. 2021, 22, 13337. https://doi.org/ 10.3390/ijms222413337

Academic Editor: Agata Adamczyk

Received: 14 October 2021

Accepted: 9 December 2021

Published: 11 December 2021

Publisher's Note: MDPI stays neutral with regard to jurisdictional claims in published maps and institutional affiliations.

Copyright: (c) 2021 by the authors Licensee MDPI, Basel, Switzerland. This article is an open access article distributed under the terms and conditions of the Creative Commons Attribution (CC BY) license (https:// creativecommons.org/licenses/by/ $4.0 /)$.

\begin{abstract}
Brain pathologies evoked by thiamine deficiency can be aggravated by mild zinc excess. Cholinergic neurons are the most susceptible to such cytotoxic signals. Sub-toxic zinc excess aggravates the injury of neuronal SN56 cholinergic cells under mild thiamine deficiency. The excessive cell loss is caused by $\mathrm{Zn}$ interference with acetyl-CoA metabolism. The aim of this work was to investigate whether and how astroglial C6 cells alleviated the neurotoxicity of Zn to cultured SN56 cells in thiamine-deficient media. Low Zn concentrations did not affect astroglial C6 and primary glial cell viability in thiamine-deficient conditions. Additionally, parameters of energy metabolism were not significantly changed. Amprolium (a competitive inhibitor of thiamine uptake) augmented thiamine pyrophosphate deficits in cells, while co-treatment with $\mathrm{Zn}$ enhanced the toxic effect on acetyl-CoA metabolism. SN56 cholinergic neuronal cells were more susceptible to these combined insults than $\mathrm{C} 6$ and primary glial cells, which affected pyruvate dehydrogenase activity and the acetyl-CoA level. A co-culture of SN56 neurons with astroglial cells in thiamine-deficient medium eliminated Zn-evoked neuronal loss. These data indicate that astroglial cells protect neurons against $\mathrm{Zn}$ and thiamine deficiency neurotoxicity by preserving the acetyl-CoA level.
\end{abstract}

Keywords: zinc toxicity; acetyl-CoA; energy metabolism; thiamine pyrophosphate

\section{Introduction}

Neurons in the brain have high energy requirements that make them particularly susceptible to metabolic stress. The impairment of glucose, oxygen or lactate provision causes energy hypometabolism, inducing several neurodegenerative disorders, e.g., Alzheimer's disease (AD) [1]. Energy failures result from a direct or an indirect inhibition of the tricarboxylic acid cycle and the electron transport chain by multiple neurodegenerative signals, such as an excess of $\mathrm{Zn}, \mathrm{Al}$ or NO, hypoxia, hypoglycemia, amyloid $\beta$-protein and hyperphospho-tau oligomerizations [2]. These factors inhibit pyruvate dehydrogenase $(\mathrm{PDH}), \alpha$-ketoglutarate dehydrogenase complexes $(\mathrm{KDH})$, and aconitase activities in mitochondria. Furthermore, the suppression of PDH activity decreases acetyl-CoA synthesis and utilization in the tricarboxylic acid (TCA) cycle [2,3]. On the other hand, a decreased acetyl-CoA level reduces cytoplasmic acetylcholine production, resulting in poor neurotransmission and decreased cell viability [2-5]. Moreover, the susceptibility of SN56 cholinergic cells to cytotoxic insults increases with the cholinergic phenotype [4,5].

Neuronal energy metabolism is affected by thiamine deficiency (TD) resulting from a thiamine-poor diet [6]. TD is identified in patients (the majority of them are chronic alcoholics) suffering from hyperemesis gravidarum, intestinal obstruction or malignancy [6].

One neuropsychiatric disorder arising from TD is called Wernicke's encephalopathy [7]. Wernicke's encephalopathy can be reversed if a patient is treated with adequate 
doses of thiamine within the first 48-72 $\mathrm{h}$ of the first clinical symptoms appearing [6]. These symptoms are caused by a disturbance in cholinergic neurotransmission. The acetylcholine (ACh) decreases, and choline acetyltransferase (ChAT) inhibition occurs in areas containing cholinergic neurons in TD brains. This preferential loss of cholinergic neurons is also one of the hallmarks in the progression of Alzheimer's disease (AD) [2]. Therefore, our working hypothesis is that energy disturbances in $\mathrm{AD}$ can by triggered by thiamine deficiency. Thiamine is phosphorylated to a pyrophosphate of thiamine (TPP) by thiamine pyrophosphokinase [7]. TPP is most highly concentrated in the human brain. Thus, thiamine deficiency leads to TPP deficits. TPP is the cofactor for the E1 subunit of PDH and $\mathrm{KDH}$ [8]. Moreover, asymptomatic forms of TPP deficiency have been frequently reported in populations of elderly people. This symptom is considered to be one that worsens the course of $\mathrm{AD}[9,10]$. Therefore, there are similarities between the cognitive dysfunction in AD and TD patients. The most important similarity is the inhibition of glucose metabolism [10]. Indeed, postmortem studies on the brain cortex of patients who died from AD show the inhibition of PDH activity [11]. However, TPP deficiency affects oxidative metabolism and function not only in neurons but in all types of glial cells. The data showed that there was an inhibition of PDH activity that caused a decrease in the metabolic flux in the synaptosomes of rats fed with pyrithamine, which is an analog of thiamine inducing thiamine deficiency [12]. The same observation was noticed in SN56 cholinergic cells cultured with amprolium, a competitive inhibitor of thiamine transport. The intracellular TPP deficit led to a decrease in acetyl-CoA and ACh synthesis due to PDH activity inhibition, which increased the mortality of the cultured neurons [2,4].

The next cytotoxic insult that has been proven to limit acetyl-CoA metabolism is an excessive release of $\mathrm{Zn}$ from glutamatergic terminals $[3,13,14]$. This phenomenon is considered to be a primary neurodegenerative signal. Under physiological conditions, $\mathrm{Zn}$ co-released with glutamate is quickly cleared from the synaptic cleft by astrocytes and postsynaptic neurons [13]. However, under pathological conditions, there is an excessive release of Zn-glutamate from depolarized glutamatergic presynaptic terminals, which increases the free $\mathrm{Zn}$ concentration (Figure 1) [15]. This is a consequence of neurotoxic factor exposure, mechanical trauma, ischemia, or TD [5]. The excess of free (unbound) $\mathrm{Zn}^{2+}$ is accumulated in depolarized postsynaptic neurons, where it inhibits PDH activity, leading to a decrease in the acetyl-CoA level. Additionally, KDH and aconitase and NADP-isocitrate dehydrogenase (ICDH-NADP) activities were inhibited by elevated $\mathrm{Zn}^{2+}$ (Figure 1) [16,17]. This is the main reason for excessive neuronal death [3]. In turn, the aberrant redistribution of $\mathrm{Zn}$ in postsynaptic cellular compartments triggers neurotoxic events [13]. However, TD aggravates the $\mathrm{Zn}^{2+}$ neurotoxicity by increasing the intracellular accumulation of the cation [5]. Moreover, the susceptibility of the neurons to $\mathrm{Zn}$ and other cytotoxic signals may differ depending on their phenotype. It has been shown that differentiated septal SN56 cholinergic cells displayed greater susceptibility to Zn excess and TD than nondifferentiated ones (Scheme 1) [2,5]. Thus, maintenance of the pyruvate-acetyl-CoA(mit)-acetyl-CoA(cyt)-ACh pathway constitutes a functional unit in cholinergic neurons.

However, earlier experiments did not take the impact of cytotoxic factors on energy metabolism in glial cells into consideration. For instance, astrocytes play an important role in maintaining neuronal homeostasis, providing lactate as a complementary energy substrate for neurons [18]. They protect neurons against different neurotoxic conditions, including heavy metal intoxication, hypoxia, and other neurodegenerative conditions [19]. The impairment of oxidative metabolism in astrocytes with thiamine deficiency may induce lactate and glutamate accumulation, causing acidosis and the excitotoxic stimulation of glutamatergic neurons $[20,21]$. To the best of our knowledge, there are no data showing whether astroglial cells are capable of protecting neuronal cells against $\mathrm{Zn}$ toxicity in TD. If this is the case, they could clear $\mathrm{Zn}$ from the neuronal vicinity, thereby protecting neurons against $\mathrm{Zn}$ overload. However, it is not known whether astroglial cells respond to marginal Zn excess in thiamine deficiency, especially in terms of their energy metabolism 
and viability. This knowledge would give us a more detailed answer about the energy metabolism in the brain. Therefore, the aim of this work was to investigate whether such protective astroglia-neuron interactions might take place under $\mathrm{Zn}$ overload in thiaminedeficient conditions. The data presented here indicate that this might be the case.
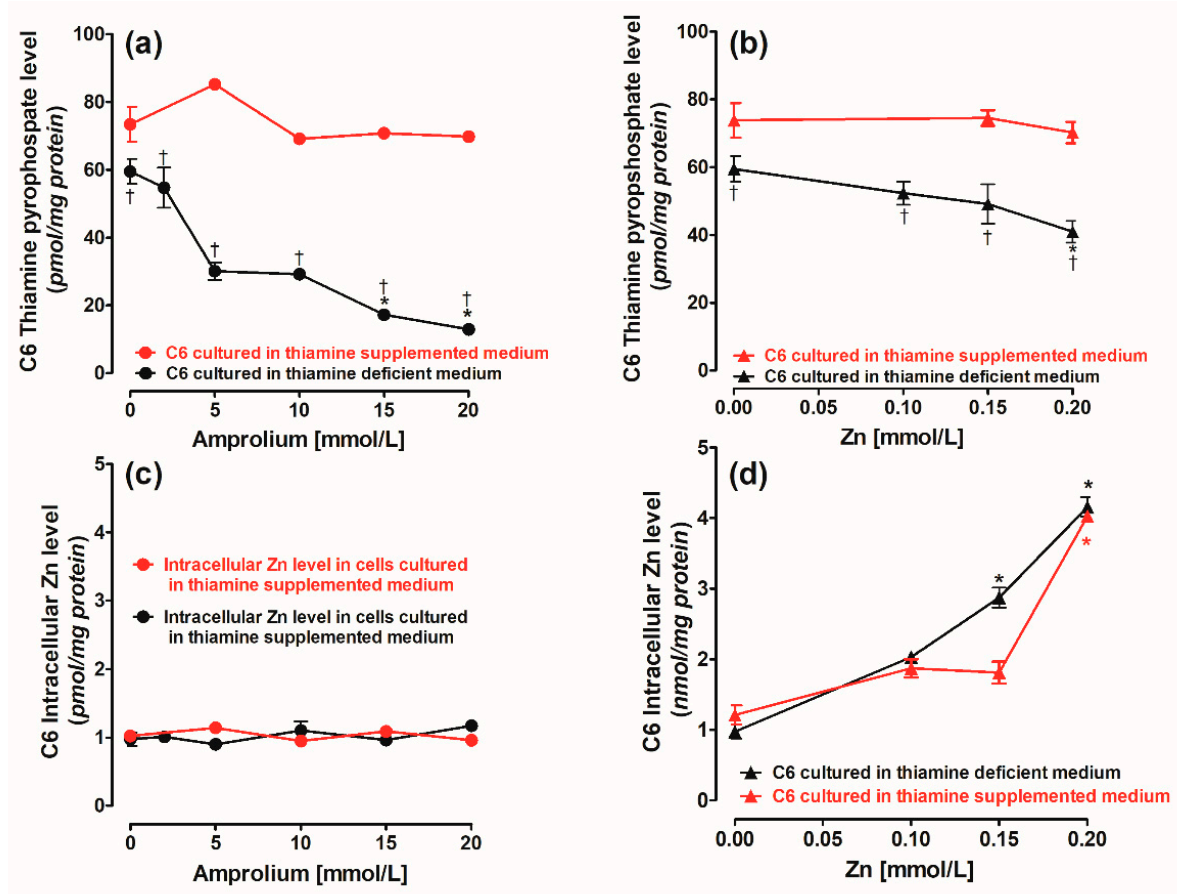

Figure 1. Concentration-dependent, chronic effects of (a) amprolium and (b) Zn on thiamine pyrophosphate (TPP) content. Chronic effects of (c) amprolium and (d) Zn on intracellular Zn level in C6 cells cultured in thiamine-deficient or supplemented medium. Data are means \pm SEM from $n=4-5$ independent cell culture preparations. Significantly different from respective controls: ${ }^{*} p<0.01$; thiamine-supplemented medium ${ }^{\dagger} p<0.01$.
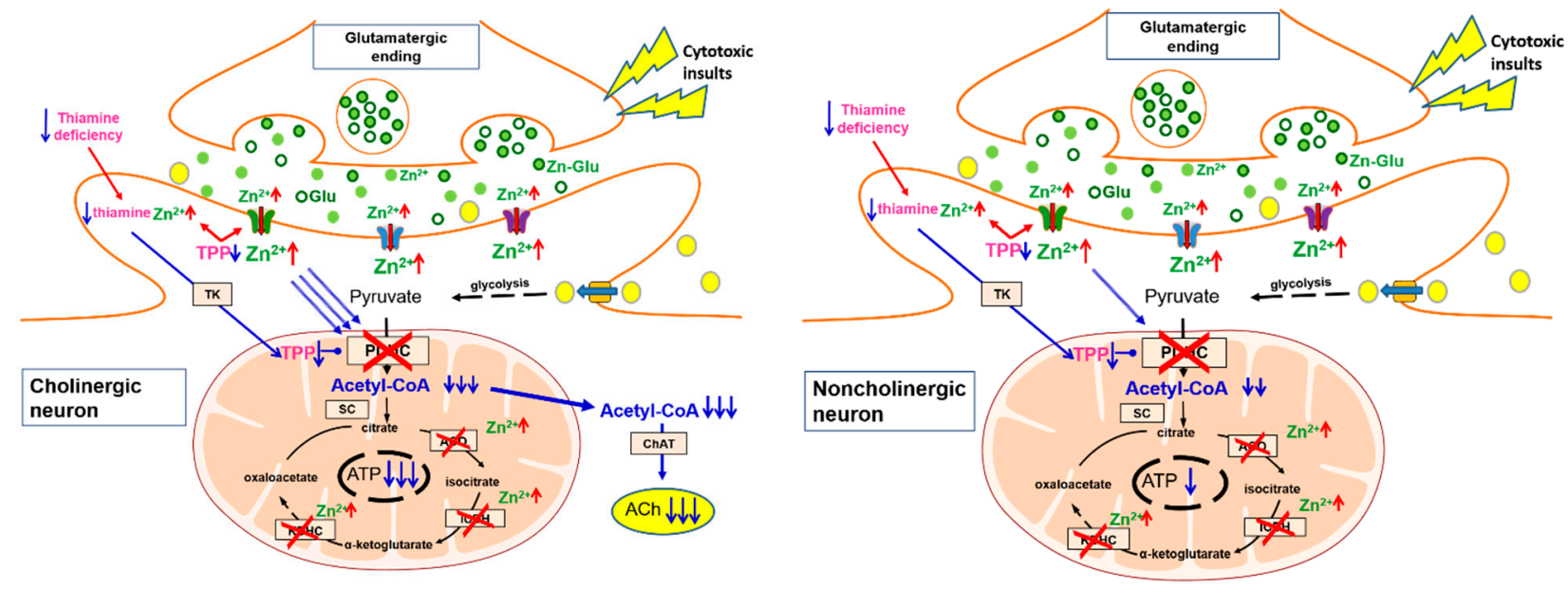

Scheme 1. Pyruvate, the final product of the glycolytic pathway, is the main precursor of acetyl-CoA synthesized by a PDH-catalyzed reaction in mitochondria. Pathologic signals associated with AD and other cholinergic encephalopathies lead to prolonged depolarization of glutamatergic terminals and excessive release of glutamate and $\mathrm{Zn}$. This causes an increased accumulation of zinc ions in postsynaptic neurons yielding direct inhibition of PDH activity. As a result, the synthesis of acetyl-CoA and its utilization in the TCA cycle are reduced. It leads to inhibition of ATP synthesis. In cholinergic neurons, the most significant fraction of the cytoplasmic acetyl-CoA pool is consumed for the synthesis of the acetylcholine. TPP deficits increase the permeability of plasma neuronal membranes for $\mathrm{Zn}$ leading to aggravation of its inhibitory effects on PDH and other enzymes of acetyl-CoA metabolism. 


\section{Results}

2.1. Concentration-Dependent Effects of Amprolium and $\mathrm{Zn}$ on Thiamine Pyrophosphate (TPP), Intracellular Zn Content, and Viability of C6 Cells and Primary Glial Cells

The TPP level was about 73 pmols $/ \mathrm{mg}$ protein in C6 cells grown in medium supplemented with $0.009 \mathrm{mmol} / \mathrm{L}$ thiamine (Figure 1a) [5]. The addition of amprolium up to $10 \mathrm{mmol} / \mathrm{L}$ to a medium supplemented with $0.009 \mathrm{mmol} / \mathrm{L}$ thiamine brought about no significant alterations in the TPP level of the tested cells (Figure 1a) [5]. Amprolium is a competitive inhibitor of the thiamine transporter and is used to aggravate a TPP deficit [21].

C6 and primary glial cells grown in a thiamine-deficient medium displayed TPP levels equal to about $60 \mathrm{pmol} / \mathrm{mg}$ protein in control (Figure 1a). In these conditions, amprolium in 5 and $10 \mathrm{mmol} / \mathrm{L}$ concentrations caused about a decrease of roughly $45 \%$ of TPP in C6 cells (Figure 1a). The increase in amprolium to $20 \mathrm{mmol} / \mathrm{L}$ brought about an $80 \%$ suppression of the TPP level (Figure 1a). $\mathrm{Zn}$ added to the cell culture in amounts up to $0.20 \mathrm{mmol} / \mathrm{L}$ did not significantly decrease the TPP intracellular level when the cells were grown in a thiamine-supplemented medium (Figure $1 \mathrm{~b}$ ). In turn, there was a $28 \%$ decrease in the intracellular TPP level at $0.20 \mathrm{mmol} / \mathrm{L} \mathrm{Zn}$ in the cells cultivated in a thiamine-deficient medium (Figure 1b).

The control intracellular $\mathrm{Zn}$ level in C6 cells was equal to $0.98 \mathrm{nmol} / \mathrm{mg}$ protein (Figure $1 \mathrm{c}, \mathrm{d}$ ). The addition of amprolium did not affect the $\mathrm{Zn}$ level (Figure 1c). To accumulate $3.0 \mathrm{nmol} / \mathrm{mg}$ protein of $\mathrm{Zn}, \mathrm{C} 6$ cells required the addition of $0.15 \mathrm{mmol} / \mathrm{L}$ of this cation to the cell culture (Figure 1d) [5].

The viability of $\mathrm{C} 6$ cells and primary glial cells was not decreased by amprolium when cells were cultured in a thiamine-supplemented medium (Figure 2a,c). However, in C6 cells, $10 \mathrm{mmol} / \mathrm{L}$ amprolium resulted in a $20 \%$ drop in the $\mathrm{C} 6$ cell number (Figure 2a) and a $25 \%$ decrease in the primary glial cell viability (Figure 2c). The increase in amprolium to $20 \mathrm{mmol} / \mathrm{L}$ brought about an $80 \%$ suppression of the cell count in C6 cultured in a thiamine-deficient medium (Figure 2a).
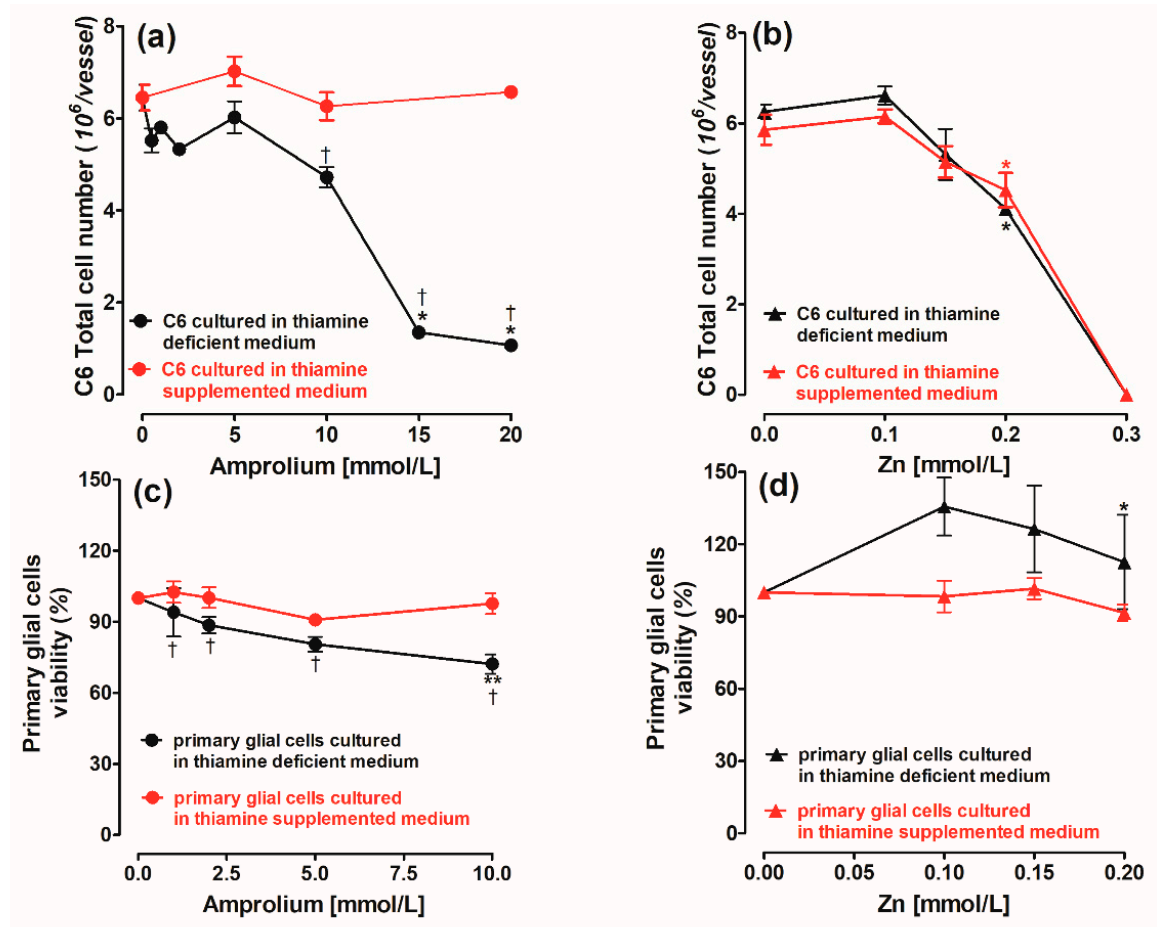

Figure 2. Concentration-dependent, chronic effects of (a) amprolium and (b) $\mathrm{Zn}$ on viability of C6 cells. Chronic effects of (c) amprolium and (d) Zn on viability of primary glial cells cultured in thiamine-deficient and thiamine-supplemented medium. Data are means \pm SEM from $n=3-4$ independent cell culture preparations. Significantly different from respective controls: ${ }^{*} p<0.01$, ${ }^{*} p<0.05$; thiamine-supplemented medium ${ }^{\dagger} p<0.01$. 
$\mathrm{Zn}$ at a $0.20 \mathrm{mmol} / \mathrm{L}$ concentration caused a roughly $25 \%$ loss of C6 cell count (Figure 2b). Furthermore, an increase in $\mathrm{Zn}$ to $0.30 \mathrm{mmol} / \mathrm{L}$ caused an instant loss of C6 cells independently of the thiamine presence in the culture media (Figure 2b). The viability of the primary glial cells measured using the MTT reduction test was not significantly changed by $\mathrm{Zn}$, irrespective of the thiamine presence in the medium (Figure 2d).

Therefore, to examine the combined effect of TD and Zn on C6 cells, 5 and $10 \mathrm{mmol} / \mathrm{L}$ amprolium and $0.15 \mathrm{mmol} / \mathrm{L} \mathrm{Zn}$ were chosen for further experiments because they did not significantly decrease cellular viability. For primary glial cells, $10 \mathrm{mmol} / \mathrm{L}$ amprolium and $0.20 \mathrm{mmol} / \mathrm{L} \mathrm{Zn}$ were chosen.

\subsection{Concentration-Dependent Effects of Amprolium and Zn on Enzymes of Energy Metabolism and Acetyl-CoA Level in C6 Cells}

Standard PDH assays are performed at saturating concentrations of substrates and cofactors including TPP. Therefore, this reflects the amount of active enzyme complex in the cells [5]. Here, we additionally used the modified assay medium without exogenous TPP to assess the fractional saturation of PDH with TPP and putative metabolic flux through this step in cells in situ [22]. The control activities of PDH measured with TPP added to the assay medium were over two times higher than those measured without this cofactor (Figure 3a,b). The PDH activity in C6 cultivated in thiamine-supplemented medium was 30\% higher than the one found in the cells grown without thiamine and was resistant to a $\mathrm{Zn}$ addition (Figure $3 \mathrm{~b}$ ). Amprolium in concentrations of $10 \mathrm{mmol} / \mathrm{L}$ brought about no alterations in PDH activity but reduced the acetyl-CoA level by about $35 \%$ in C6 cells cultured in thiamine-deficient MEM (Figure 3a,c). In the same conditions, $0.15 \mathrm{mmol} / \mathrm{L} \mathrm{Zn}$ did not alter the enzyme activity or the acetyl-CoA levels (Figure $3 \mathrm{~b}, \mathrm{~d}$ ). Higher concentrations of $0.20 \mathrm{mmol} / \mathrm{L} \mathrm{Zn}$ reduced the PDH activity and the acetyl-CoA level, respectively, by 50 and $75 \%$ (Figure $3 b, d$ ).
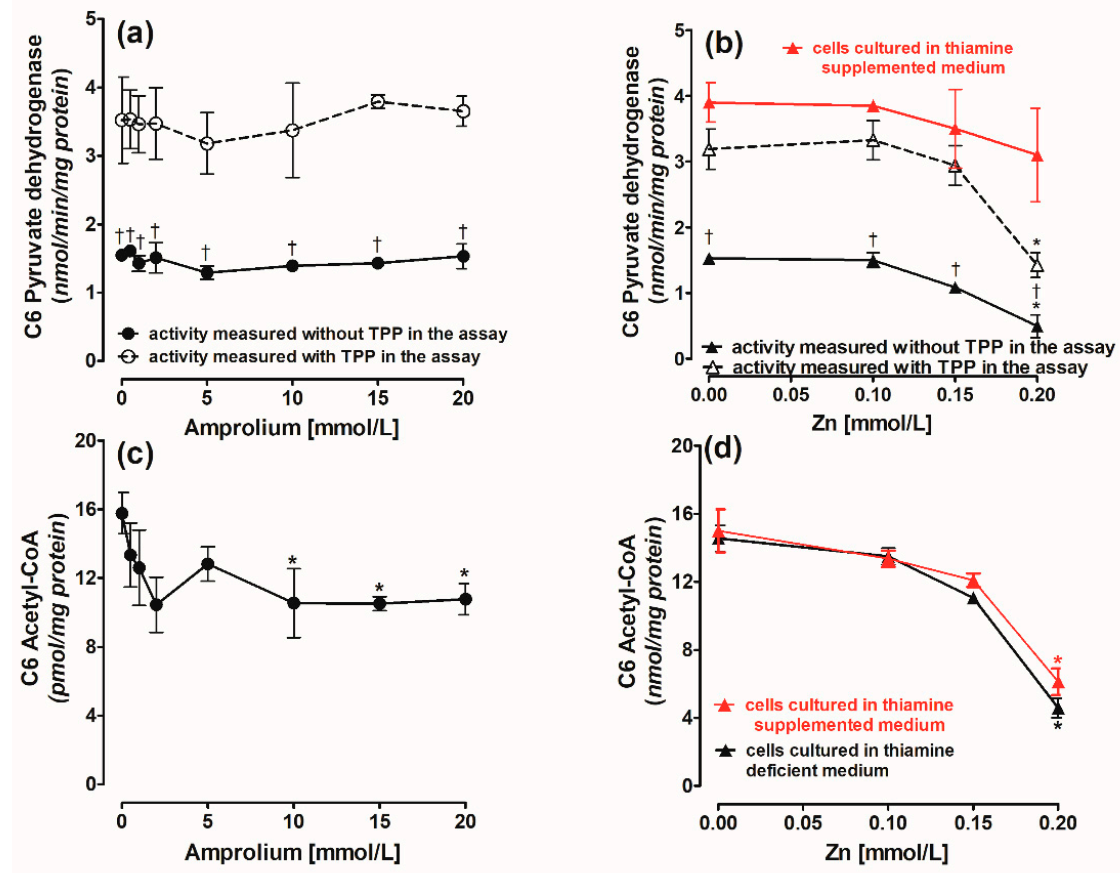

Figure 3. Concentration-dependent chronic effects of (a) amprolium and (b) Zn on PDH activity in C6 cells cultured in thiamine-deficient or -supplemented medium and assayed in the presence or absence of TPP in the assay medium. Chronic effects of (c) amprolium and (d) Zn on acetyl-CoA level in $\mathrm{C} 6$ cells cultured in thiamine-deficient or thiamine-supplemented medium. Data are means \pm SEM from $n=3-4$ independent cell culture preparations. Significantly different from respective controls: ${ }^{*} p<0.01 ; \mathrm{PDH}$ activity in TPP containing assay medium ${ }^{\dagger} p<0.01$. 
Aconitase and ICDH-NADP activities in C6 cells were not significantly inhibited by $10 \mathrm{mM}$ amprolium (Figure $4 \mathrm{a}, \mathrm{c}$ ) or $0.15 \mathrm{mM}$ Zn (Figure $4 \mathrm{~b}, \mathrm{~d}$ ). Higher concentrations of $20 \mathrm{mmol} / \mathrm{L}$ amprolium and $0.20 \mathrm{mmol} / \mathrm{L} \mathrm{Zn}$ resulted in a 73 and $50 \%$ inhibition of aconitase (Figure $4 a, b)$ and no major alterations in ICDH-NADP activities, respectively (Figure $4 \mathrm{c}, \mathrm{d}$ ).
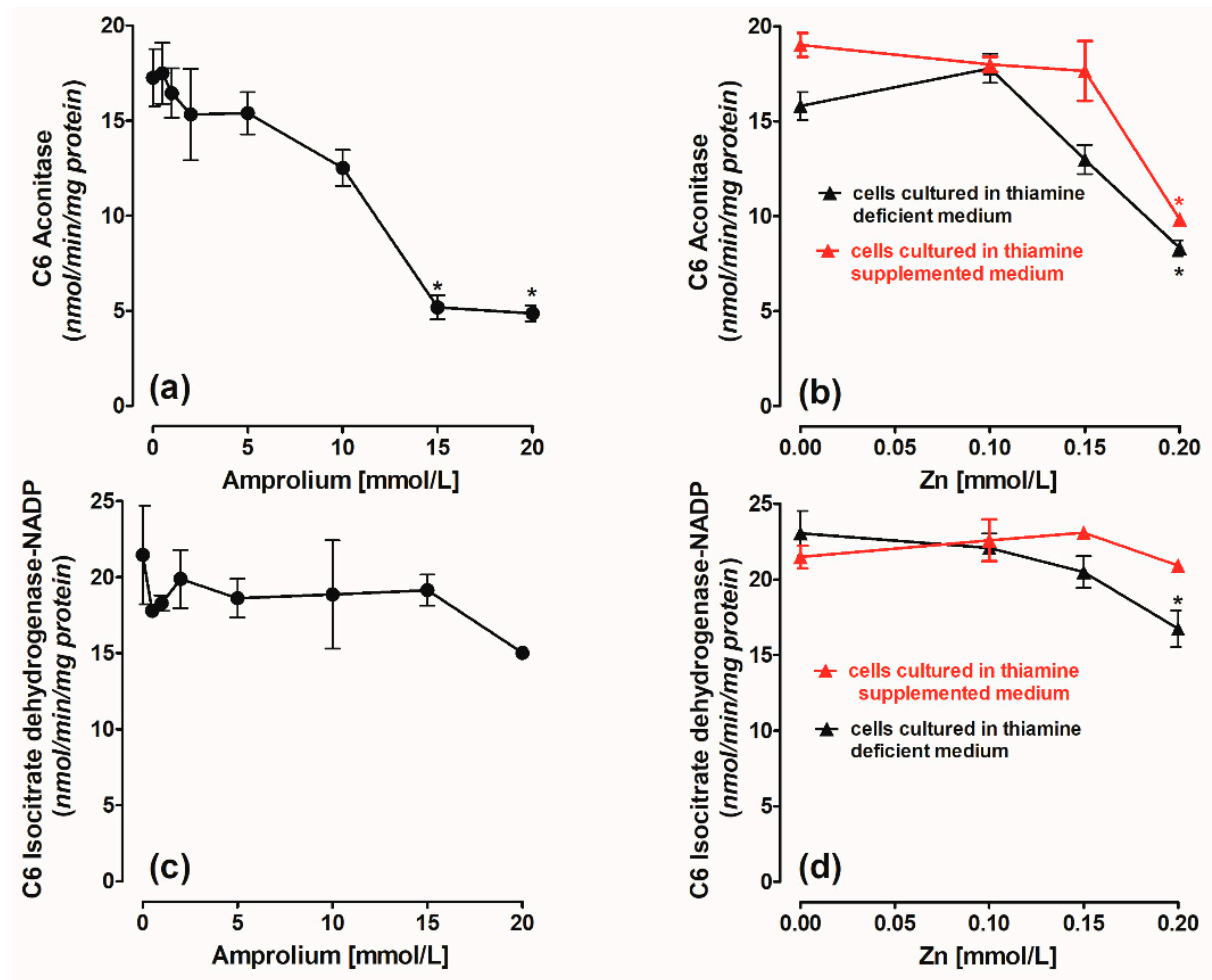

Figure 4. Concentration-dependent chronic effects of (a) amprolium and (b) Zn on aconitase activity. Chronic effects of (c) amprolium and (d) $\mathrm{Zn}$ on isocitrate dehydrogenase-NADP (ICDH-NADP) activity in C6 cells cultured in thiamine-deficient or thiamine-supplemented medium. Data are means \pm SEM from $n=3-4$ independent cell culture preparations. Significantly different from respective controls: ${ }^{*} p<0.01$.

Amprolium at $10 \mathrm{mmol} / \mathrm{L}$ and $\mathrm{Zn}$ at $0.15 \mathrm{mmol} / \mathrm{L}$ were chosen for studies of their combined toxicity on $\mathrm{C} 6$ and primary glial cells on the basis of the data presented in Figures 1-4. On the other hand, $5 \mathrm{mmol} / \mathrm{L}$ amprolium and $0.10 \mathrm{mmol} / \mathrm{L} \mathrm{Zn}$ alone were harmful for SN56 cholinergic neuronal cells, and this cytotoxicity was aggravated by their combined use [5]. On the other hand, the same concentrations of the compounds were not toxic for $\mathrm{C} 6$ cells cultivated in a thiamine-deficient medium (Figures 2-5). Therefore, the latter concentrations of amprolium and $\mathrm{Zn}$ were used to study the putative neuroprotective effects of C6 astroglial cells on SN56 cells. 

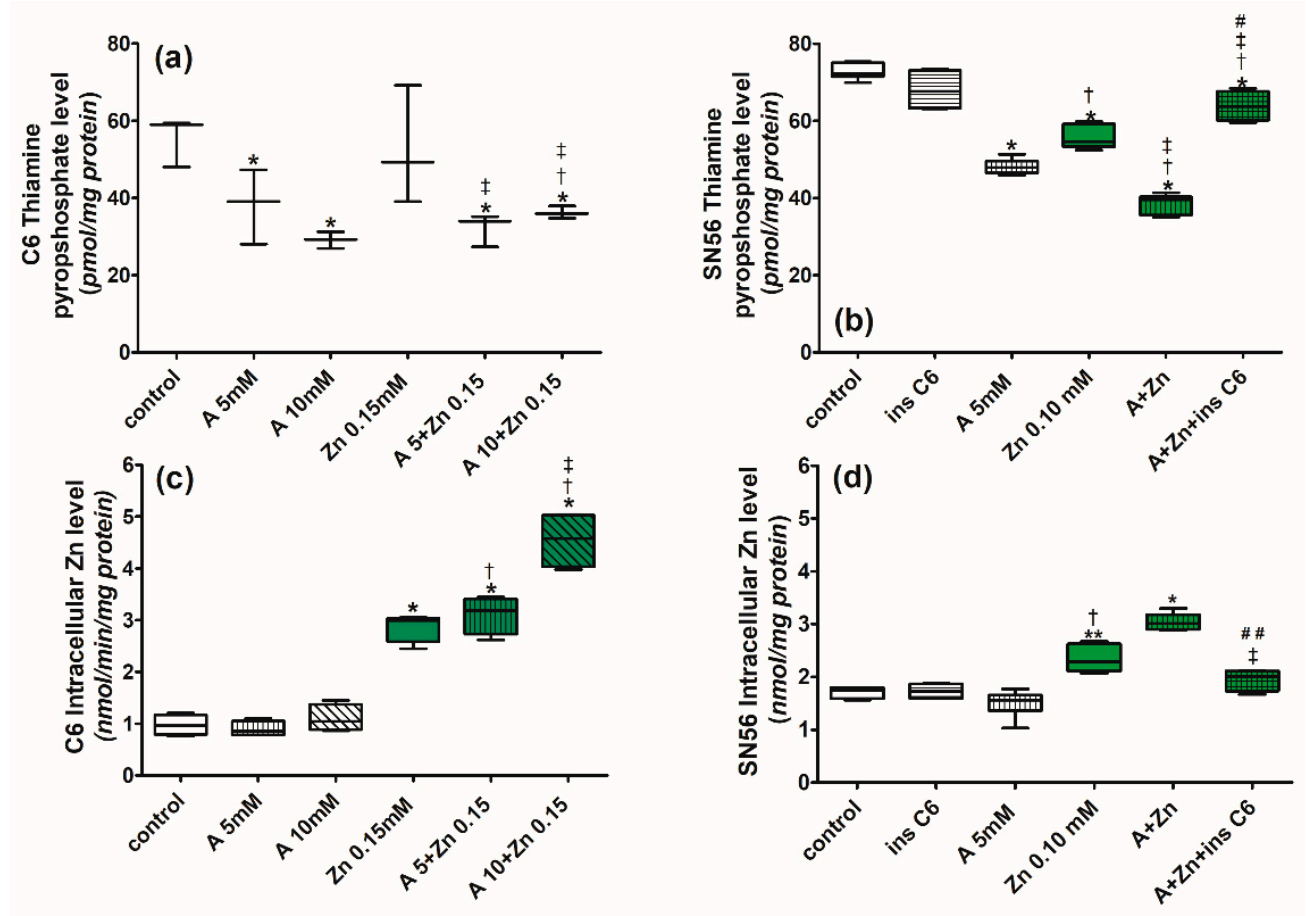

Figure 5. Chronic effects of amprolium and $\mathrm{Zn}$ on (a) TPP level and (c) intracellular $\mathrm{Zn}$ level in C6 cells cultured in thiamine-deficient medium. Chronic effects of amprolium, Zn, and inserts with C6 cells on (b) TPP level and (d) intracellular Zn content in SN56 cells cultured in thiaminedeficient medium. Data are median \pm Whiskers: Min to Max from $n=4-6$ independent cell culture preparations. Significantly different from respective controls: ${ }^{* *} p<0.01,{ }^{*} p<0.05$; amprolium ${ }^{+} p<0.05 ; \mathrm{Zn} \ddagger p<0.05 ; \mathrm{A}+\mathrm{Zn}{ }^{\# \#} p<0.01,{ }^{\#} p<0.05$.

\subsection{Combined Cytotoxic Effects of Zn and Thiamine Deficits on C6 Astroglial and SN56 Cholinergic Neuronal Cells. The Effect of C6 Inserts on SN56 Cells}

\subsubsection{The Effects of Zn, Amprolium, and C6 Inserts on Intracellular TPP and Zn Levels}

There was a roughly 35\% reduction in the intracellular TPP content in C6 astroglial or SN56 cells cultured in a thiamine-deficient medium with $5 \mathrm{mmol} / \mathrm{L}$ amprolium alone (Figure 5a,b). The $0.10 \mathrm{mmol} / \mathrm{L} \mathrm{Zn}$ alone brought about a 25\% reduction in TPP in SN56 cells (Figure 5b), and none in C6 cells. Zn did not enhance the suppressive effects of amprolium on the TPP levels in C6 (Figure 5a), but it augmented its deficit to 50\% in SN56 cells (Figure 5b) [5]. To study the interaction between C6 and SN56 cells, we co-cultured SN56 with C6 seeded on cell culture inserts (with a 0.40-micrometer pore, 3-centimeter diameter). The intracellular TPP level was not changed in SN56 cells cultured with C6 inserts against the control (Figure 5b). However, the presence of C6 inserts prevented a TPP decrease in the SN56 cells exposed simultaneously to amprolium and Zn (Figure 5b).

The intracellular $\mathrm{Zn}$ level was not changed by the addition of 5 and $10 \mathrm{mmol} / \mathrm{L}$ amprolium in C6 cells (Figure 5c). Nonetheless, it was elevated over four times by 0.15 $\mathrm{mmol} / \mathrm{L} \mathrm{Zn}$ and $5 \mathrm{mmol} / \mathrm{L}$ amprolium (Figure 5c). Amprolium and C6 inserts alone did not change the intracellular Zn content in the SN56 cells (Figure 5d). The exposure of the SN56 neuronal cells to $0.10 \mathrm{mmol} / \mathrm{L} \mathrm{Zn}$ and $5 \mathrm{mmol} / \mathrm{L}$ amprolium resulted in a partially additive increase in intraneuronal $\mathrm{Zn}$ content from 1.74 to $2.49 \mathrm{nmol} / \mathrm{mg}$ protein (Figure 5d). Inserts with C6 cells prevented Zn elevation in SN56 cells (Figure 5d).

2.3.2. The Effects of Zn, Amprolium, and C6 Inserts on PDH Activity, Acetyl-CoA Level, and the Total Cell Number

Amprolium (5 mmol/L) as a sole cytotoxic factor did not affect the PDH activities in the C6 and SN56 cells (Figure 6a,b). Zn alone did not inhibit the enzyme's activity in C6 cells (Figure 6a) but there was a 50\% inhibition of PDH in SN56 cells (Figure 6b). 
The combined addition of $10 \mathrm{mmol} / \mathrm{L}$ amprolium and $0.15 \mathrm{mmol} / \mathrm{L} \mathrm{Zn}$ brought about no significant decrease in PDH activity in the C6 cells (Figure 6a). On the other hand, $5 \mathrm{mmol} / \mathrm{L}$ amprolium and $0.10 \mathrm{mmol} / \mathrm{L} \mathrm{Zn}$ caused a total inhibition of PDH activity in the SN65 cells (Figure 6b). The insert of C6 cells did not alter the basal PDH activity in SN56 but partially prevented amprolium+Zn-evoked inhibition (Figure $6 \mathrm{~b}) . \mathrm{Zn}(0.15 \mathrm{mmol} / \mathrm{L})$ or amprolium $(10 \mathrm{mmol} / \mathrm{L})$ alone caused a roughly $15 \%$ decrease in the acetyl-CoA level in a thiamine-deficient medium in C6 cells (Figure 6c). The combined use of these factors augmented acetyl-CoA suppression to $50 \%$ (Figure 6c). The acetyl-CoA level was reduced by about $30 \%$ in the SN56 neuronal cells cultured with $5 \mathrm{mmol} / \mathrm{L}$ amprolium or $0.10 \mathrm{mmol} / \mathrm{L} \mathrm{Zn}$ alone in a thiamine-deficient medium (Figure $6 \mathrm{~d}$ ). The joint addition of these compounds caused a 63\% drop in the neuronal acetyl-CoA level. The inserts of C6 cells reversed this suppressive effect (Figure 6d).
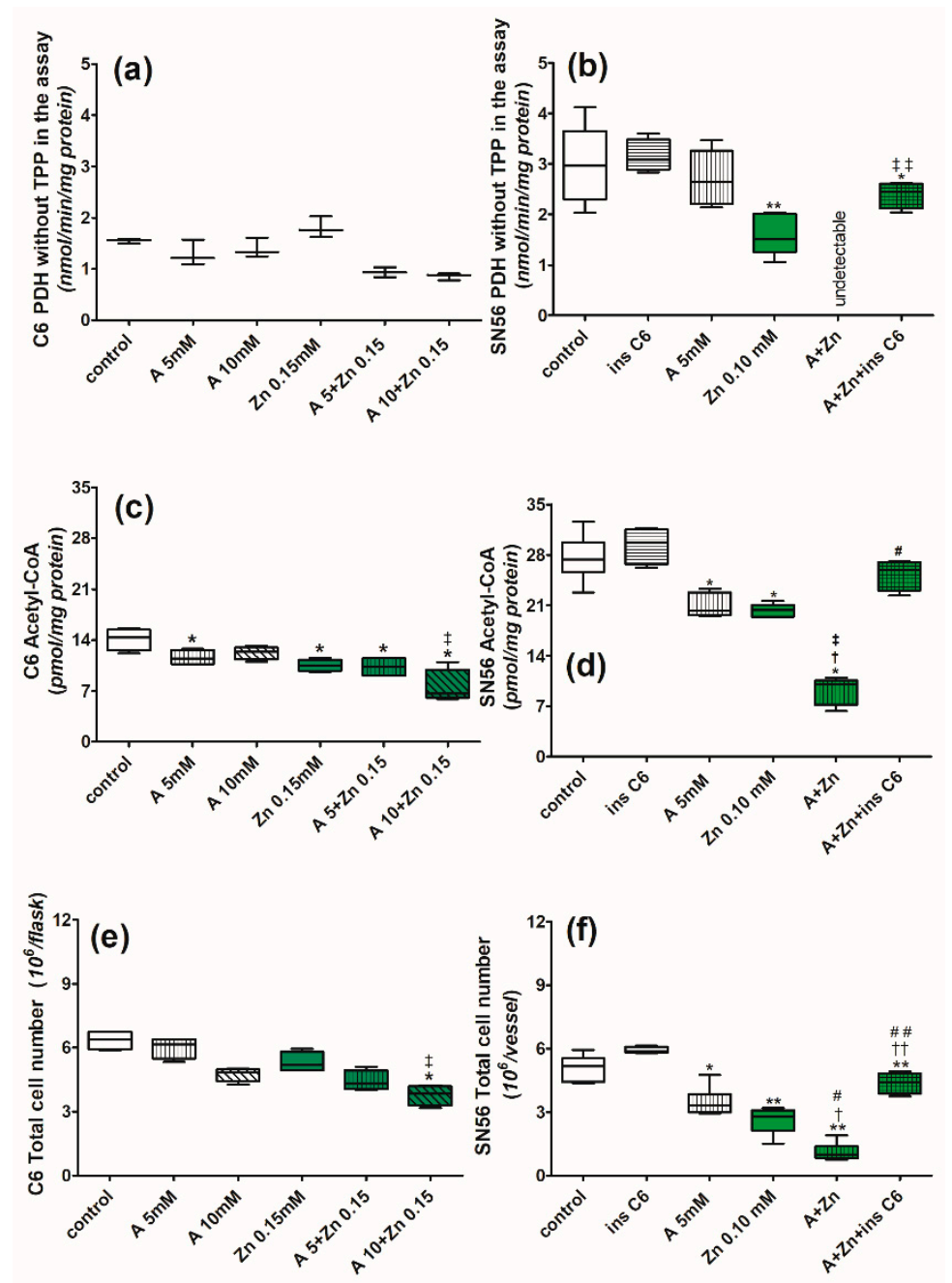

Figure 6. Chronic effects of amprolium and $\mathrm{Zn}$ on (a) PDH activity, (c) acetyl-CoA level, (e) total count of $\mathrm{C} 6$ cells cultured in thiamine-deficient medium. PDH was assayed in TPP-free assay medium. Chronic effects of amprolium, Zn, and inserts with C6 cells on (b) PDH activity, (d) total acetyl-CoA level, and (f) count of SN56 cells cultured in thiamine-deficient medium. Data are median \pm Whiskers: Min to Max from $n=4-6$ independent cell culture preparations. Significantly different from respective controls: ${ }^{* *} p<0.01,{ }^{*} p<0.05$; amprolium ${ }^{+\dagger} p<0.01,{ }^{\dagger} p<0.05$, respectively, $\mathrm{Zn}$ 㧊 $p<0.01, \ddagger p<0.05 ; \mathrm{A}+\mathrm{Zn}{ }^{\# \#} p<0.01,{ }^{\#} p<0.05$.

The total number of $\mathrm{C} 6$ cells was not significantly decreased by a separate treatment of amprolium or $\mathrm{Zn}$. However, a combined culture with these compounds brought about a 34\% drop in the C6 cell number (Figure 6e). Single additions of amprolium or $\mathrm{Zn}$ to 
cultured SN56 cells caused 35 and 45\% decreases in their number, respectively (Figure 6f). The combined use of $\mathrm{Zn}$ and amprolium aggravated the SN56 cell number depletion by $80 \%$ (Figure $6 \mathrm{f}$ ). Inserts of C6 cells brought back the SN56 cell number to $85 \%$ of the control level (Figure 6f).

2.3.3. The Effects of Zn and Amprolium and C6 Inserts on the Activities of Selected Enzymes of the TCA Cycle

The chronic exposure of C6 cells to a thiamine-deficient medium at $0.15 \mathrm{mmol} / \mathrm{L} \mathrm{Zn}$ or $10 \mathrm{mmol} / \mathrm{L}$ amprolium alone resulted in a 25 and $30 \%$ inhibition of aconitase activity (Figure 7a). The enzyme's activity was inhibited by $52 \%$ by a combined use of these factors (Figure 7a). There were no alterations in ICDH-NADP activities (Figure 7c). The aconitase activity in neuronal SN56 cells was not affected by $5 \mathrm{mmol} / \mathrm{L}$ amprolium.
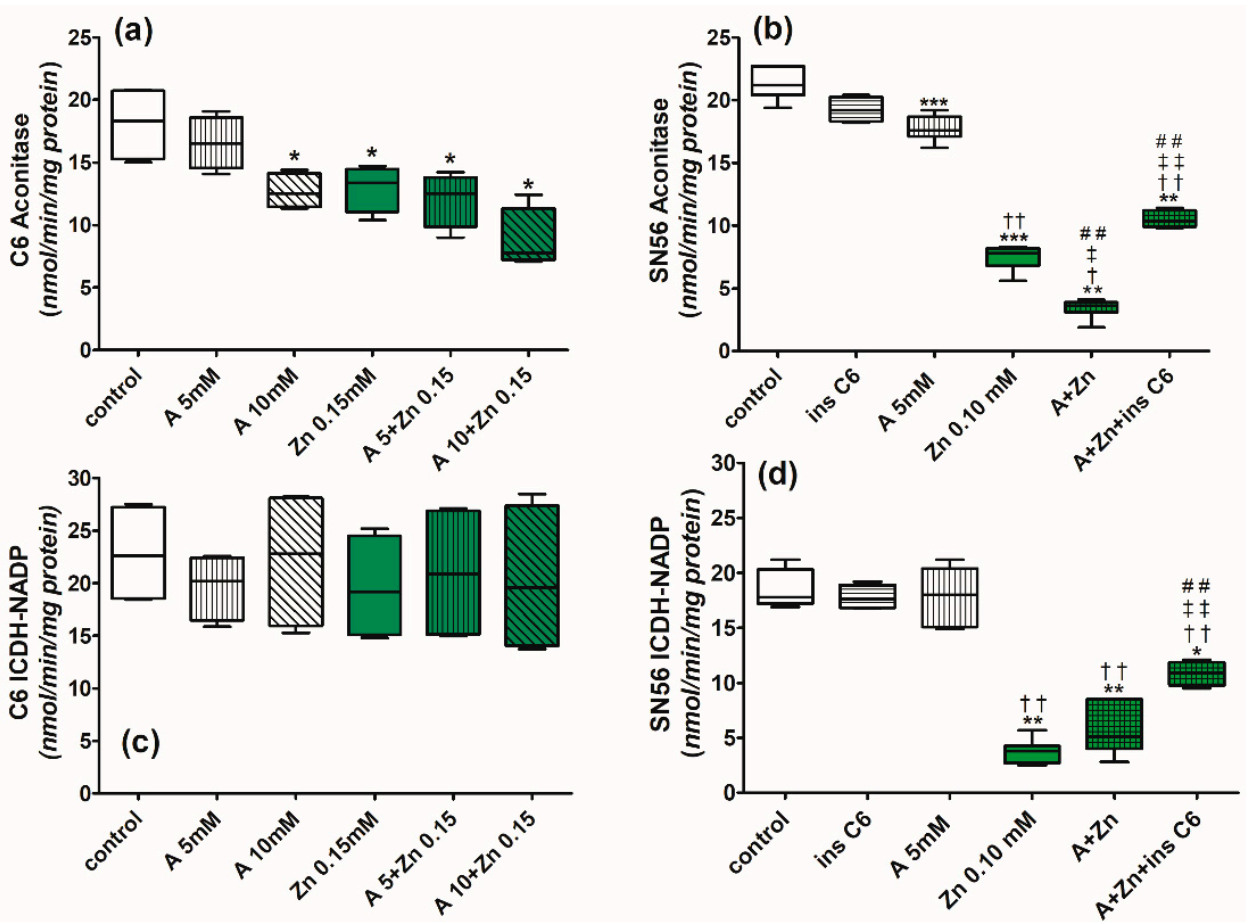

Figure 7. Chronic effects of amprolium and $\mathrm{Zn}$ on (a) aconitase activity and (c) ICDH-NADP activity in $\mathrm{C} 6$ cells cultured in thiamine-deficient medium. Chronic effects of amprolium, $\mathrm{Zn}$, and inserts with C6 cells on (b) aconitase activity and (d) ICDH-NADP activity in SN56 cells cultured in thiaminedeficient medium. Data are median \pm Whiskers: Min to Max from $n=4-6$ independent cell culture preparations. Significantly different from respective controls: ${ }^{* *} p<0.005,{ }^{* *} p<0.01,{ }^{*} p<0.05$; amprolium ${ }^{\dagger+} p<0.01,{ }^{\dagger} p<0.05 ; \mathrm{Zn}$ 护 $p<0.01,{ }^{\ddagger} p<0.05 ; \mathrm{A}+\mathrm{Zn}{ }^{\# \#} p<0.01$.

The enzyme was inhibited by $66 \%$ with $0.10 \mathrm{mmol} / \mathrm{L} \mathrm{Zn}$ (Figure $7 \mathrm{~b}$ ). In turn, amprolium $+Z n$ inhibited aconitase activity by $86 \%$ in the SN56 cells (Figure 7b). Inserts of C6 cells did not alter aconitase activity. They reversed the inhibitory effect of amprolium $+\mathrm{Zn}$ on aconitase activity by $50 \%$ (Figure $7 \mathrm{~b}$ ). Amprolium had no effect on ICDH-NADP activity in neuronal SN56 cells (Figure 7d). On the other hand, Zn alone or Zn+amprolium inhibited enzyme activity by 85 and $75 \%$, respectively (Figure $7 d$ ). Inserts of C 6 cells partially reversed this inhibition in SN56 neuronal cells (Figure 7d).

\subsection{Combined Effects of Amprolium and Zn on Metabolic Parameters of Primary Glial Cells}

Amprolium in $10 \mathrm{mmol} / \mathrm{L}$ concentrations added to a medium supplemented with $0.009 \mathrm{mmol} / \mathrm{L}$ thiamine brought about no significant alterations in the TPP level.

Primary glial cells grown in thiamine-deficient medium displayed TPP levels equal to about $60 \mathrm{pmol} / \mathrm{mg}$ protein in the control (Figure $8 \mathrm{a}$ ). In these conditions, $10 \mathrm{mmol} / \mathrm{L}$ 
amprolium caused a $24 \%$ decrease in the intracellular TPP content (Figure 8a). Separate additions of $10 \mathrm{mmol} / \mathrm{L}$ amprolium or $0.20 \mathrm{mmol} / \mathrm{L} \mathrm{Zn}$ caused 24 and $20 \%$ decreases in the intracellular TPP content (Figure 8a). The suppressive effects on the TPP content were augmented by the combined application of the tested compounds (Figure 8a).
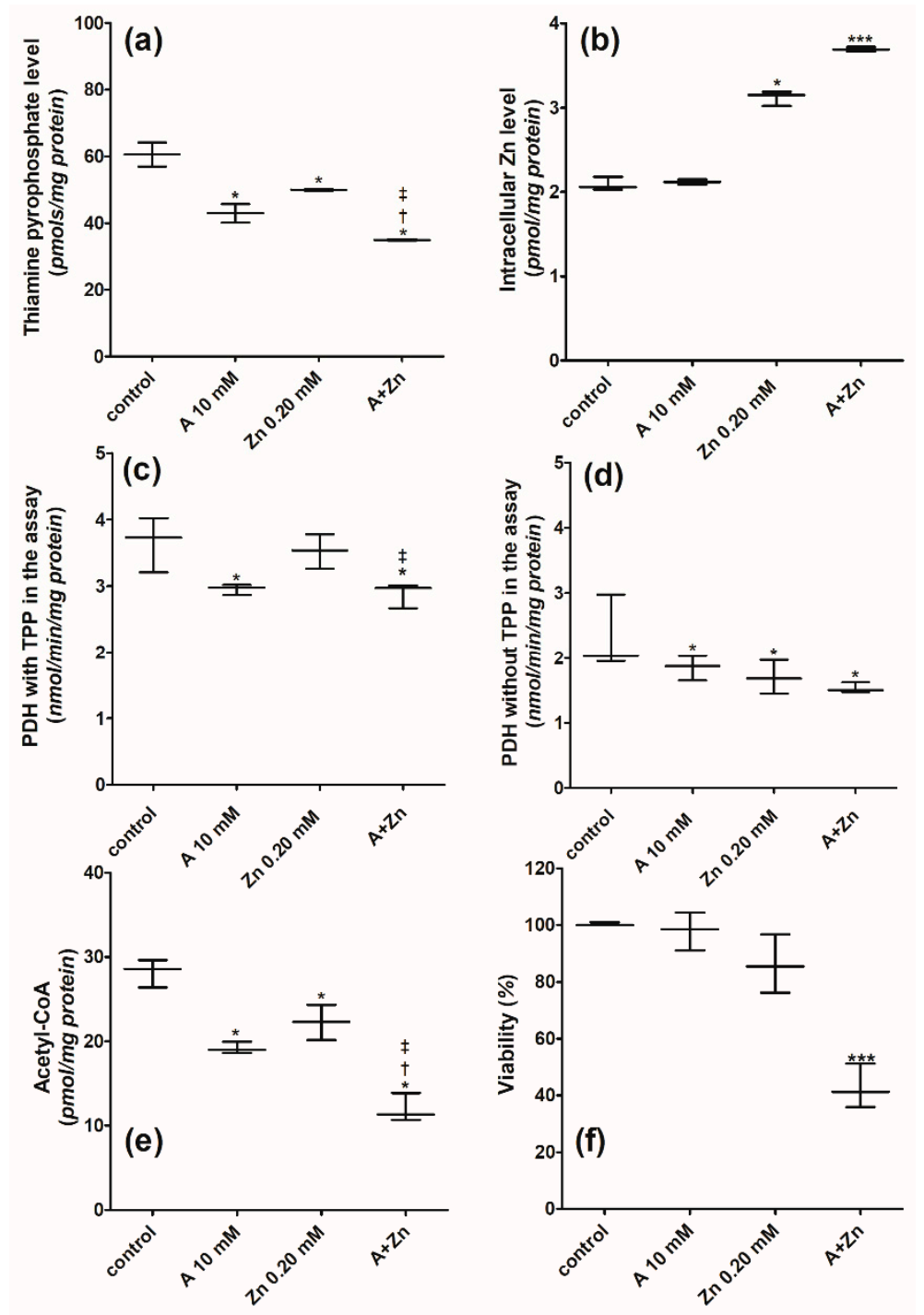

Figure 8. Chronic effects of amprolium and $\mathrm{Zn}$ on (a) thiamine pyrophosphate (TPP) content, (b) intracellular $\mathrm{Zn}$ content, (c) PDH activity measured in saturated TPP concentration in the assay medium; (d) PDH activity measured in the absence of TPP in the assay medium; (e) total acetyl-CoA level; (f) viability of primary glial cells grown in thiamine-deficient medium. Data are median \pm Whiskers: Min to Max from $n=4-6$ independent cell culture preparations. Significantly different from respective controls: ${ }^{* *} p<0.005,{ }^{*} p<0.05$; amprolium ${ }^{\dagger} p<0.05 ; \mathrm{Zn}{ }^{\ddagger} p<0.05$.

The control intracellular $\mathrm{Zn}$ level in primary glial cells was equal to $2.09 \mathrm{nmol} / \mathrm{mg}$ protein (Figure 8b). Amprolium did not change the intracellular Zn level (Figure 8b), but this level was elevated to $3.12 \mathrm{nmol} / \mathrm{mg}$ protein in cells cultured with $0.20 \mathrm{mmol} / \mathrm{L} \mathrm{Zn}$ (Figure $8 \mathrm{~b}$ ). A culture with $10 \mathrm{mmol} / \mathrm{L}$ amprolium and $0.20 \mathrm{mmol} / \mathrm{L} \mathrm{Zn}$ caused a further increase in the intracellular $\mathrm{Zn}$ level to $3.69 \mathrm{nmol} / \mathrm{mg}$ protein (Figure $8 \mathrm{~b}$ ).

The metabolic parameters of primary glial cells were tested here to verify whether the properties of clonal C6 cells may be comparable to those of primary glial cells.

The activity of PDH was 50\% lower when measured in the presence of TPP in the assay medium (Figure $8 \mathrm{c}, \mathrm{d}$ ). There was a $20 \%$ decrease in PDH activity at $10 \mathrm{mmol} / \mathrm{L}$ amprolium in both of the tested assay media (Figure $8 \mathrm{c}, \mathrm{d}$ ). $\mathrm{Zn}$ in concentrations of $0.20 \mathrm{mmol} / \mathrm{L}$ 
inhibited the enzyme's activity by $26 \%$ only in the assay without TPP (Figure $8 \mathrm{~d}$ ). Amprolium $+Z n$ caused a $23 \%$ inhibition of PDH activity in the presence of TPP in the assay medium (Figure 8c). Yet, amprolium $+\mathrm{Zn}$ caused a $35 \%$ inhibition of $\mathrm{PDH}$ activity without TPP in the assay medium (Figure $8 \mathrm{~d}$ ). The PDH activity inhibition by $10 \mathrm{mmol} / \mathrm{L}$ amprolium or $0.20 \mathrm{mmol} / \mathrm{L} \mathrm{Zn} \mathrm{led} \mathrm{to} \mathrm{a} \mathrm{roughly} 30 \%$ acetyl-CoA level drop (Figure 8e). This effect was aggravated over two times by the combined use of amprolium and $\mathrm{Zn}$ (Figure 8e). It caused over a $50 \%$ loss of cellular viability measured by the MTT reduction rate (Figure $8 \mathrm{f}$ ).

\section{Discussion}

There are a number of experimental data presenting the separate, detrimental effects of either Zn excess or thiamine deficiency (TD) on the energy metabolism and survival of brain cells [23]. Our recent study proved that there is an enhancement of $\mathrm{Zn}$ accumulation caused by TPP deficiency in cholinergic neuronal cells [5]. This caused a decrease in neuronal viability and neurotransmission by its interaction with acetyl-CoA metabolism. On the other hand, to the best of our knowledge, there are no data on interactions between these pathological signals in glial cells. Since astroglia take an active role in the maintenance of neuronal homeostasis in the brain, knowledge of their metabolism in toxic conditions would be essential to prevent neurodegeneration. Therefore, the presented study investigated the combined effects of minor Zn excess and TD on key steps of energy metabolism in astroglial cells. Then, the influence of astroglial cells on neighboring neuronal SN56 septal cholinergic cells subjected to cytotoxic insults was studied. The obtained results might help to explain the role of astroglia in the early stages of neurodegeneration.

The C6 astroglial cell line was used as model of neuroprotection within this study. Primary astrocyte cultures create difficulties in studying their energy metabolism parameters because of the limitation of their growth. On the other hand, a C6 culture is an isolated system. Yet, it has been demonstrated recently that $\mathrm{C} 6$ cells show a similar gene expression to isolated astrocytes [24]. However, both types of cells displayed a similar response and susceptibility to $\mathrm{Zn}$ excess. C6 required 0.15 and primary glial cells $0.20 \mathrm{mmol} / \mathrm{L} \mathrm{Zn}$ in the culture medium to accumulate its intracellular level of about $3.0 \mathrm{nmol} / \mathrm{mg}$ protein. This led to a $25 \%$ loss of their viability. Furthermore, the presented data indicate that a culture of C6 glial and primary glial cells in a thiamine-deficient medium caused a similar, slight 24-28\% decrease in their TPP content. This drop did not significantly affect the growth rate, the acetyl-CoA level, or the aconitase and ICDH-NADP activities in C6 and primary glial cells. This is why such deficits are marginal for them. On the other hand, a drop in TPP caused a 30\% inhibition of PDH activity in glial cells. The same was observed in TD cholinergic SN56 cells, which preserved parameters of viability, but PDH activity was inhibited in conditions of marginal thiamine deficiency $[5,23]$. These findings are compatible with studies on TD rats, which demonstrated no apparent symptoms of TD at $20 \%$ decreases in the TPP levels in their brains [25]. This indicates that C6 clonal cells may constitute the in vitro model of TD in astroglial cells. Decreases in the TPP levels in rat's brains or human serum of more than $50 \%$ decreased PDH activity, leading to overt clinical and pathological symptoms [12,26]. However, under moderate TD conditions, neurons and glial cells displayed different susceptibility. For instance, treatment with amprolium alone decreased TPP levels by about 20,31 , and $48 \%$, respectively, in primary glial cells, SN56, and C6 cells. However, there was only reduced viability in SN56 neuronal cells. This indicates that there is a relative resistance of glial cells to moderate TPP deficits. This may be a promising phenomenon for neuroprotection against cytotoxic insults.

Within this study, we used an additional cytotoxic factor: Zn excess. This aggravated the decrease in the TPP level both in C6 and primary glial cells. In consequence, there was a similar suppression of PDH activity and the acetyl-CoA level and a marked decrease in their viability.

The cells also displayed a variable susceptibility to $\mathrm{Zn}$ excess. Thus, there was a 50\% inhibition of SN56 viability at $0.10 \mathrm{mmol} / \mathrm{L} \mathrm{Zn}$, a $15 \%$ inhibition of $\mathrm{C} 6$ at $0.15 \mathrm{mmol} / \mathrm{L}$, whereas primary glial cells did not lose their viability even at a $0.20 \mathrm{mmol} / \mathrm{L} \mathrm{Zn}$ concentra- 
tion. The mortality of SN56 was accompanied by corresponding alterations in PDH activity (Table 1). It is known that the cytotoxic effects of Zn on cultured SN56 neuronal cells appear above $0.10 \mathrm{mmol} / \mathrm{L}$ when its concentration exceeds the binding capacity of the serum proteins present in a standard culture medium [14,17]. Therefore, the estimated concentration of ionic $\mathrm{Zn}$ in the growth medium is equal to about $0.01 \mathrm{mmol} / \mathrm{L}$ in such conditions $[17,27]$. Therefore, concentrations of free $\mathrm{Zn}^{2+}$ in the presence of 0.15 and $0.20 \mathrm{mmol} / \mathrm{Zn}$ in the culture medium in the $\mathrm{C} 6$ and primary astroglia media are equal to 0.06 and $0.11 \mathrm{mmol} / \mathrm{L}$, respectively. Previous data showed that $0.01 \mathrm{mmol} / \mathrm{L} \mathrm{Zn}^{2+}$ exerted a significant toxic effect on SN56 in a thiamine-deficient medium (Table 1a). This indicates that a relatively minor excess of $\mathrm{Zn}^{2+}$ in the extracellular fluid is able to penetrate plasma membranes and accumulate in the TD neurons. It may result from a several-fold increase in 1,2 L-type Ca channel levels in TD neurons [28,29]. However, glial cells displayed a different capacity for accumulate and buffer $\mathrm{Zn}^{2+}$ because they have diverse transporting and complexing systems. In fact, neuronal cells expressing high levels of the $\mathrm{ZnT}$ protein and mRNA have a high affinity for voltage gated calcium channels and present a fast $\mathrm{Zn}^{2+}$ uptake [30] (Table 1a). Indeed, neuronal cells cultured in TD media with only $0.10 \mathrm{mmol} / \mathrm{L} \mathrm{Zn} \mathrm{accumu-}$ lated $2.3 \mathrm{nmols} / \mathrm{mg}$ protein. On the other hand, glial cells needed higher additions of 0.15 and $0.20 \mathrm{mmol} / \mathrm{L} \mathrm{Zn}$ to TD culture media to accumulate a similar level of this cation. Thus, astrocytes have an affinity but high capacity for $\mathrm{Zn}$ accumulation. Furthermore, they are more resistant to $\mathrm{Zn}$ excess than neuronal cells. Therefore, at $0.10 \mathrm{mmol} / \mathrm{L} \mathrm{Zn}, \mathrm{C} 6$ astroglia stayed viable and retained their neuroprotective properties.

Table 1. Comparison of the cytotoxic effects of (a) $\mathrm{Zn}$ and (b) combined exposure of cells to amprolium and $\mathrm{Zn}$ in TD medium on selected parameters of different types of brain cells.

\begin{tabular}{|c|c|c|c|}
\hline Parameter & $\begin{array}{c}\text { SN56 Cells } \\
+ \text { Zn } 0.10 \\
\text { mmol/L }\end{array}$ & $\begin{array}{c}\text { C6 Cells } \\
+\mathrm{Zn} 0.15 \mathrm{Zn} \mathrm{mmol} / \mathrm{L}\end{array}$ & $\begin{array}{l}\text { Primary Glial Cells } \\
+ \text { Zn } 0.20 \mathrm{Zn} \mathrm{mmol} / \mathrm{L}\end{array}$ \\
\hline $\begin{array}{l}\text { PDH with TPP in the assay } \\
\text { (\% inhibition) }\end{array}$ & 29 & 10 & 3 \\
\hline $\begin{array}{l}\text { PDH without TPP in the assay } \\
\text { (\% inhibition) }\end{array}$ & 47 & 25 & 23 \\
\hline $\begin{array}{l}\text { Acetyl-CoA } \\
\text { (\% decrease) }\end{array}$ & 20 & 24 & 22 \\
\hline $\begin{array}{l}\text { Aconitase } \\
\text { (\% inhibition) }\end{array}$ & 67 & 18 & not measured \\
\hline $\begin{array}{c}\text { TPP } \\
\text { (\% decrease) }\end{array}$ & 25 & 11 & 20 \\
\hline $\begin{array}{c}\text { Intracellular Zn } \\
\text { (nmol/mg protein) }\end{array}$ & 1.71 & 2.87 & 3.12 \\
\hline $\begin{array}{l}\text { Viability } \\
\text { (\% decrease) }\end{array}$ & 50 & 15 & 0 \\
\hline b. Parameter & $\begin{array}{c}\text { SN56 Cells } \\
\text { +A } 5 \mathrm{mmol} / \mathrm{L} \\
+\mathrm{Zn} 0.10 \mathrm{mmol} / \mathrm{L}\end{array}$ & $\begin{array}{c}\text { C6 Cells } \\
+\mathrm{A} 10 \mathrm{mmol} / \mathrm{L} \\
+\mathrm{Zn} 0.15 \mathrm{mmol} / \mathrm{L}\end{array}$ & $\begin{array}{l}\text { Primary Glial Cells } \\
\text { +A } 10 \mathrm{mmol} / \mathrm{L} \\
\text { +Zn } 0.20 \mathrm{Zn} \mathrm{mmol} / \mathrm{L}\end{array}$ \\
\hline $\begin{array}{l}\text { PDH with TPP in the assay } \\
\text { (\% inhibition) }\end{array}$ & 48 & 0 & 23 \\
\hline $\begin{array}{l}\text { PDH without TPP in the assay } \\
\text { (\% inhibition) }\end{array}$ & 100 & 45 & 35 \\
\hline $\begin{array}{l}\text { Acetyl-CoA } \\
\text { (\% decrease })\end{array}$ & 66 & 47 & 61 \\
\hline $\begin{array}{l}\text { Aconitase } \\
\text { (\% inhibition) }\end{array}$ & 85 & 52 & not measured \\
\hline $\begin{array}{l}\text { TPP } \\
\text { (\% decrease) }\end{array}$ & 48 & 35 & 42 \\
\hline $\begin{array}{l}\text { Intracellular Zn } \\
\text { (nmol/mg protein) }\end{array}$ & 3.03 & 4.54 & 3.69 \\
\hline $\begin{array}{l}\text { Viability } \\
\text { (\% decrease })\end{array}$ & 77 & 41 & 54 \\
\hline
\end{tabular}

Data for SN56 cells were taken from Ronowska et al., 2021 and Figures 5 and 6; for C6 cells data were taken from Figures 3, 5 and 6; for primary glial cells data were taken from Figure 8. 
Combined applications of amprolium and $\mathrm{Zn}$ resulted in similar 48,32 and $42 \%$ deficits of TPP in tested cells (Table 1b). However, PDH activity was inhibited with a different strength. For example, there was total PDH activity inhibition in SN56 neuronal cells by about $40 \%$ in both types of glial cells. This indicates that the lack of TPP as the PDH cofactor may not be the only factor responsible for the inhibition of the enzyme activity that leads to viability loss of neuronal cells in cytotoxic conditions (Table 1b). Nevertheless, both neuronal and astroglial cells possess similar mechanisms of thiamine transport and the conversion of thiamine to TPP yielding its similar distribution along all the cellular compartments of the brain [21]. However, the greater sensitivity of SN56 to TD and other cytotoxic insults may be due to the fact that acetyl-CoA is used both for energy production and acetylcholine synthesis. Therefore, cholinergic neurons require much higher PDH activity for acetyl-CoA synthesis. On the other hand, the PDH activity in glial cells was two times lower than in neuronal cells and more resistant to $\mathrm{Zn}$ excess. This is compatible with the faster rate of glycolysis and slower pyruvate metabolism in astroglia than in neuronal cells $[19,31]$. Additionally, the activity of PDH in glial cells was resistant to moderate $\mathrm{Zn}$ inhibition, thereby preserving the acetyl-CoA level for energy production in the tricarboxylic acid cycle (Table 1a). This might be explained by the fact that there is an increased level of the S100A6 protein in both primary and clonal astrocytes in response to $\mathrm{Zn}$ overload [32]. This may be the reason for the greater resistance of C6 and primary glial cells to isolated zinc excess in thiamine-deficient conditions (Figure 9c). Thus, astroglia may exert neuroprotective effects by taking up $\mathrm{Zn}$ excess from the neuronal vicinity [19]. This thesis is supported here by the data, indicating that C6 inserts accumulate higher amounts of $\mathrm{Zn}$ than SN56 cells in neurotoxic conditions (Figure 9a-d).

TPP deficits caused by amprolium enhanced the $\mathrm{Zn}^{2+}$ uptake into the tested cells. However, the influx was differentiated in the various cell types. Moreover, the PDH activity and acetyl-CoA level depended more heavily on the intracellular Zn level in SN56 than in C6 cells (Figure 9a,b). In this case, aggravated Zn uptake is only crucial for neuronal survival (Figure 9c). Therefore, there is only a significant correlation between the TPP level and $\mathrm{Zn}$ accumulation in neuronal cells (Figure 9d). This indicates that the viability of neurons strongly depends on PDH-derived acetyl-CoA. That is why any cytotoxic signal that inhibits PDH activity causes excessive neuronal death. Such a significant dependence was not observed in glial cells. However, only very high $\mathrm{Zn}$ concentrations did inhibit $\mathrm{PDH}$ activity in glial cells in thiamine-deficient conditions (Scheme 1). The mechanism of $\mathrm{Zn}$ and amprolium cytotoxicity on PDH is based on the removal of lipoamide from the E2 subunit, whereas amprolium suppressed the E1 subunit by the TPP depletion of its active centre [16]. This indicates the existence of a dual mechanism of PDH susceptibility. Therefore, $\mathrm{Zn}$ affects both neurons and astroglia but with a different potency.

$\mathrm{Zn}$ also inhibited aconitase activity by the displacement of $\mathrm{Fe}^{2+}$ from its active centre [17]. The inhibition of aconitase by Zn in C6 was weaker than in SN56 cells, which may be an additional factor contributing to the higher susceptibility of neuronal cells to Zn excess (Table 1, Figure 9e). The strong inhibition of ICDH-NADP by Zn may be an additional complementary factor hampering only SN56 viability. On the other hand, the lack of ICDH-NADP activity inhibition by $\mathrm{Zn}$ in $\mathrm{C} 6$ cells may promote their resistance against the accumulation of this cation (Figure 9f). This indicates that astroglial cells may retain their functional capacity in conditions harmful for neuronal cells.

Thanks to these properties, C6 astroglial cells protect the neuronal SN56 cells against $\mathrm{TD}$ and $\mathrm{Zn}$ toxicity. The neuroprotective effects of $\mathrm{C} 6$ astroglial cells may be caused by a decreased Zn accumulation and an increased TPP level in neuronal SN56 cells, and by a higher $\mathrm{Zn}^{2+}$ uptake. Thereby, $\mathrm{C} 6$ cells prevented the inhibition of PDH activity and acetyl-CoA synthesis, yielding the maintenance of neuronal viability. 

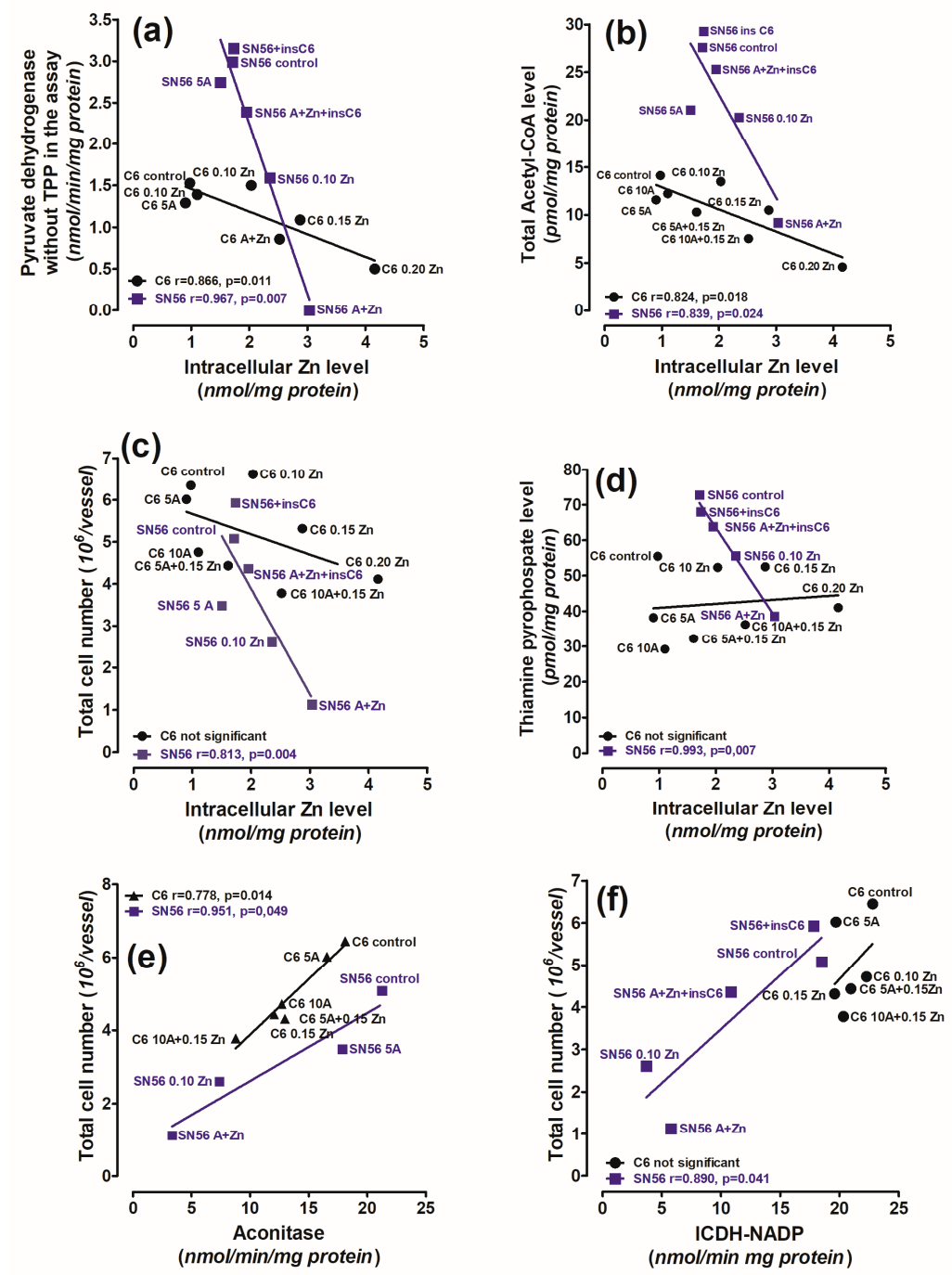

Figure 9. The correlations between (a) PDH activity assessed in assay medium without TPP against intracellular Zn content; (b) acetyl-CoA level against intracellular Zn content; (c) total cell number against intracellular Zn content; (d) TPP level against intracellular Zn content; (e) total cell number against aconitase activity, (f) total cell number against ICDH-NADP activity in C6 and SN56 cells cultured in thiamine-deficient medium. Data were taken from Figures 5-7.

\section{Materials and Methods}

\subsection{Cell Cultures}

The glioblastoma C6 cell line (RRID: CVCL 0194) and cholinergic neuroblastoma SN56.B5G4 cells (RRID: CVCL 4456) were used as models of Zn excess and TPP deficit cytotoxicity [5]. The SN56 cells were checked for their cholinergic phenotype routinely once a month by an acetylcholine level measurement, which should be no less than $30 \mathrm{pmols} / \mathrm{mg}$ protein in highly differentiated cholinergic cells. The C6 cells were verified by binding with CD11b (Invitrogen, Waltham, MA, USA) antibody or RAN (Invitrogen, Waltham, MA, USA), respectively, with the use of the MACS system (Miltenyi Biotec GmbH, BergishGladbach, Germany). Cells of all lines were grown in Minimal Eagle Medium, (MEM) (Merck SA, Darmstadt, Germany), containing $1 \mathrm{mmol} / \mathrm{L}$ L-glutamine, $0.05 \mathrm{mg}$ of streptomycin, and $50 \mathrm{U}$ of penicillin per $1 \mathrm{~mL}$, and 10\% fetal bovine serum (endogenous $\mathrm{Zn}$, $0.005 \mathrm{mmol} / \mathrm{L}$ and undetectable thiamine; thiamine-deficient medium) (Merck SA, Darmstadt, Germany). The cells cultured in MEM contained TPP levels (a derivate of thiamine) $20 \%$ lower than the cells grown in MEM supplemented with $0.009 \mathrm{mmol} / \mathrm{L}$ thiamine. The number of passages before each experiment was 2 for all cell lines. Cells were seeded on 10 -centimeter-diameter plates at a density of $40.000 / \mathrm{cm}^{2}$, and grown in MEM (thiamine- 
deficient medium) at $37{ }^{\circ} \mathrm{C}$ in an atmosphere of $5 \% \mathrm{CO}_{2}, 95 \%$ air for $48 \mathrm{~h}$. At this time, the growth medium was replaced by fresh MEM experimental medium, containing Zn (Avantor Performance Materials, Gliwice, Poland), amprolium (Merck SA, Darmstadt, Germany), or both, as indicated. The culture was continued for the next $24 \mathrm{~h}$. Amprolium, a competitive inhibitor of thiamine transport, was used to aggravate intracellular TPP deficiency. The complete reference medium was obtained by the addition of $0.009 \mathrm{mmol} / \mathrm{L}$ thiamine.

Culture was terminated by harvesting the cells in $10 \mathrm{~mL}$ of ice cold $154 \mathrm{mmol} / \mathrm{L}$ $\mathrm{NaCl}$ containing $5 \mathrm{mmol} / \mathrm{L}$ glucose and $10 \mathrm{mmol} / \mathrm{L}$ phosphate buffer (pH 7.4) (Avantor Performance Materials, Gliwice, Poland). Then, the cells were collected by centrifugation and suspended in $320 \mathrm{mmol} / \mathrm{L}$ sucrose with $0.10 \mathrm{mmol} / \mathrm{L}$ EDTA and $10 \mathrm{mmol} / \mathrm{L} \mathrm{Na}-$ HEPES (pH 7.4) to obtain $10 \mathrm{mg} / \mathrm{mL}$ protein concentration. Each sample was aliquoted for Trypan Blue assay, metabolite and enzyme assays.

To determine the effect of $\mathrm{C} 6$ astroglial cells on $\mathrm{Zn}$ neurotoxicity in neurons in thiamine deficiency, highly differentiated neuronal cholinergic SN56.B5G4 [33] cells were co-cultured with $\mathrm{C} 6$ cells. The glial C6 cells $\left(3 \times 10^{5}\right)$ were seeded on 3-centimeter-diameter inserts with a semipermeable bottom. After $24 \mathrm{~h}$ of preconditioning, 3 inserts were placed on each 10-centimeter plate with SN56 cells. The whole culture was continued in the thiaminedeficient medium for $24 \mathrm{~h}$. Then, the amprolium, $\mathrm{Zn}$ or both were added as indicated, and co-culture was continued for a subsequent $24 \mathrm{~h}$ (Scheme 2).

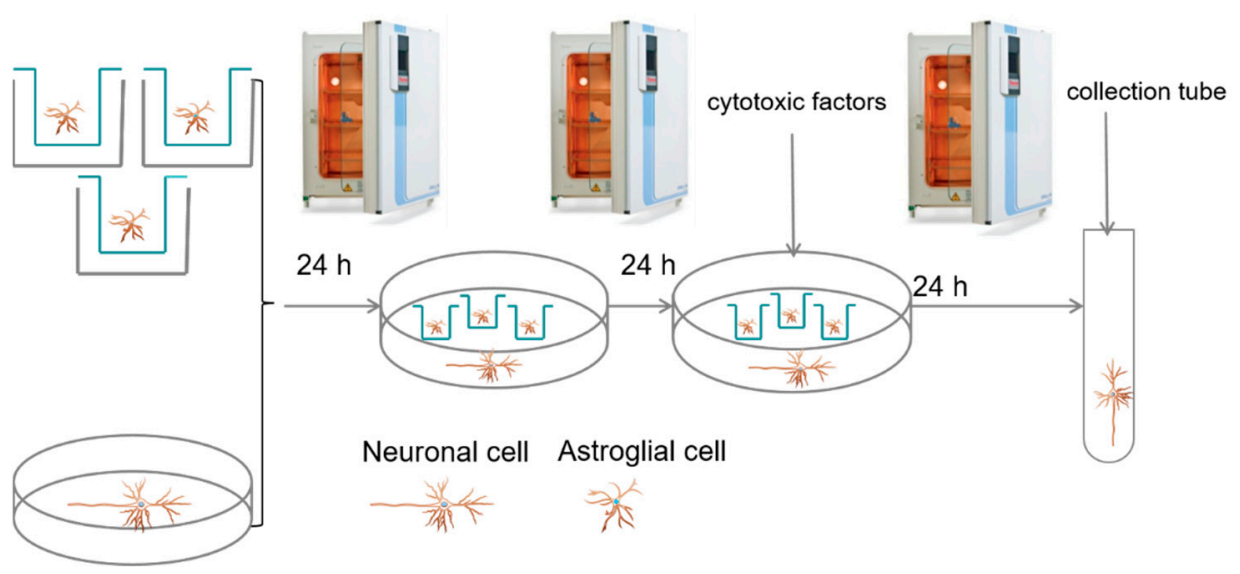

Scheme 2. The glial C6 cells $\left(3 \times 10^{5}\right)$ were seeded on 3-centimeter-diameter inserts with a semipermeable bottom. After $24 \mathrm{~h}$ of preconditioning, the 3 inserts were placed on each 10 -centimeter plate with SN56 cells. The whole culture was continued in the thiamine-deficient medium for $24 \mathrm{~h}$. Then, the amprolium or/and $\mathrm{Zn}$ were added as indicated, and co-culture was continued for a subsequent $24 \mathrm{~h}$.

Primary glial cells were isolated from C57BL/6 mice (RRID: IMSR CRL: 27). The animals were taken from the Tri-City Academic Laboratory Animal Centre. They were housed in the following controlled conditions: constant temperature, $22 \pm 1{ }^{\circ} \mathrm{C}$; humidity, 50-60\%; 12:12 dark-light cycle. The project was approved by the Ethics Commission on Animal Experiments at the Medical University of Gdańsk (permission no. 27/2013). No exclusion criteria were pre-determined. The animals were quickly euthanized by cervical dislocation. No procedure was used before euthanasia. Immediately afterwards, cerebral cortices were removed and mechanically dissociated in $\mathrm{Ca}^{2+}$ and $\mathrm{Mg}^{2+}$ free balanced salt solution, $\mathrm{pH}=7.4$, containing (in mmol/L) $137 \mathrm{NaCl}, 5.36 \mathrm{KCl}, 0.27 \mathrm{Na}_{2} \mathrm{HPO}_{4}, 1.1$ $\mathrm{NaH}_{2} \mathrm{PO}_{4}$, and 6.1 glucose (Avantor Performance Materials, Gliwice, Poland). The cortices were cleaned of meninges and mechanically dissociated by sequential passage through a Pasteur pipette. The pellet was suspended in a small amount of DMEM supplemented with $0.05 \mathrm{mg}$ of streptomycin and $50 \mathrm{U}$ of penicillin per $1 \mathrm{~mL}$ and $10 \%$ FBS and then counted. The cells were seeded on a 96-well plate $\left(12 \times 10^{4}\right.$ cell/well $)$ or 3-centimeter-diameter plates $\left(10 \times 10^{5}\right)$, pre-treated with poly-L-lysine and grown in DMEM at $37^{\circ} \mathrm{C}$ in an atmosphere 
of $5 \% \mathrm{CO}_{2}$ and $95 \%$ air. The medium was changed for a fresh one every 3 days. Cells were allowed to grow to confluence and used at 21 days in vitro. This culture time was sufficient for selection of primary glial cells. Then, the medium was changed to MEM, and amprolium or $\mathrm{Zn}$ were added as indicated. The study was not preregistered, and no randomization was performed to allocate subjects in the study.

Blinding procedures were used as indicated: the cell culture and statistics were conducted by the experimenter; viability tests, the enzymes' activities, acetyl-CoA, $\mathrm{Zn}$, and TPP levels' measurements were performed by different investigators working on randomized samples.

\subsection{Viability Assays: Trypan Blue Exclusion Test, MTT Test}

Equal volumes of Trypan Blue solution (Merck SA, Darmstadt, Germany) and 0.4\% $(w / v)$ isotonic were added to the 0.02-milliliter C6 and SN56 cell suspensions. The total cell number and fraction of nonviable, dye-accumulating cells were counted under a light microscope after $2 \mathrm{~min}$ in a Fuchs-Rosenthal hemocytometer.

The 3-(4,5-dimethylthiazol-2-yl)-2,5-diphenyltetrazolium bromide (MTT) reduction assay (Merck SA, Darmstadt, Germany) was performed in primary glial cells cultured in 96-well microplates with cytotoxic compounds as indicated for $24 \mathrm{~h}$. Then, the medium was discharged and a fresh one was added with $0.60 \mathrm{mmol} / \mathrm{L} \mathrm{3-94,5-dimethylthiazol-2-}$ yl)-2,5-diphenyltetrazolium bromide (MTT). The incubation was continued for the next $3 \mathrm{~h}$. Reduced chromophore was determined by a spectrophotometric measurement at $570 \mathrm{~nm}[34]$.

\subsection{Enzyme Assays}

For enzyme assays, cells were lysed and diluted to the desired protein concentration with $0.20 \%$ Triton X-100. PDH (EC 1.2.4.1) activity was estimated using the citrate synthase coupled method. This was assayed by measurement of synthesized acetyl-CoA followed by citrate metabolism and citrate lyase. The incubation media at a final volume of $0.25 \mathrm{~mL}$ consisted of (in mmol/L) 50 Tris $/ \mathrm{HCl} \mathrm{pH} \mathrm{=} \mathrm{8.3,} 2 \mathrm{MgCl}_{2}, 10$ dithiotreitol, $2 \mathrm{NAD}$, pyruvic acid, $0.20 \mathrm{CoA}, 2.5$ oxaloacetic acid, $0.15 \mathrm{~J} . \mathrm{M}$ citrate synthase, 2 thiamine pyrophosphate (Merck SA, Darmstadt, Germany), and $0.05 \mathrm{~mL}$ of tested sample containing $0.10 \mathrm{mg}$ of protein. To measure the activity of the enzyme in situ, thiamine pyrophosphate was not added to the incubation medium. The cells were incubated with media for $30 \mathrm{~min}$ at $37^{\circ} \mathrm{C}$. The reaction was terminated by exposing the sample to $99^{\circ} \mathrm{C}$ for $10 \mathrm{~min}$. After centrifugation at 10,000 rpm, the level of citrate was measured. The media for citrate measurement at the final volume of $0.70 \mathrm{~mL}$ consisted of (in mmol/L) 100 Tris/ $\mathrm{HCl}$ buffer $\mathrm{pH}=7.4,0.10 \mathrm{NADH}, 0.2$ J.M. malic dehydrogenase (Merck SA, Darmstadt, Germany), and $0.20 \mathrm{~mL}$ of tested sample. The reaction was initiated by the addition of $0.1 \mathrm{~J} . \mathrm{M}$. citrate lyase. The activity was expressed in mmols of oxidized NADH on the basis of an absorbance

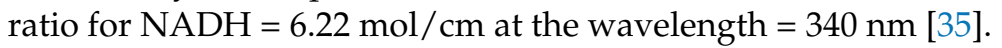

Aconitase (EC 4.2.1.3) and isocitrate dehydrogenase (EC 1.1.1.42) activities were measured by a direct measurement of NADP (Merck SA, Darmstadt, Germany) reduction. The incubation media for aconitase at the final volume of $0.80 \mathrm{~mL}$ consisted of (in mmol/L) 50 Tris/ $\mathrm{HCl} \mathrm{pH} \mathrm{=} \mathrm{7.4,} 2 \mathrm{MgCl}_{2}, 0.10$ NADP, 1 J.M. isocitrate dehydrogenase (Merck SA, Darmstadt, Germany), and $0.10 \mathrm{~mL}$ of tested sample containing $0.10 \mathrm{mg}$ of protein. The reaction was initiated by the addition of $0.01 \mathrm{~mL}$ of $20 \mathrm{mM}$ cis-akonitane (Merck SA, Darmstadt, Germany) [36].

The incubation media for isocitrate dehydrogenase at the final volume of $0.70 \mathrm{~mL}$ consisted of (in mmol/L) 50 Tris $/ \mathrm{HCl} \mathrm{pH}=7.4,0.60 \mathrm{MgCl}_{2}, 0.50 \mathrm{NADP}$, and $0.10 \mathrm{~mL}$ of tested sample containing $0.10 \mathrm{mg}$ of protein. The reaction was initiated by the addition of $0.01 \mathrm{~mL}$ of $10 \mathrm{mmol} / \mathrm{L}$ isocitrate [37]. 


\subsection{Acetyl-CoA Assay}

The acetyl-CoA level was assessed after incubation of the cells in the depolarizing medium with shaking at $100 \mathrm{cycles} / \mathrm{min}$ for $30 \mathrm{~min}$ at $37^{\circ} \mathrm{C}$. The medium consisted, at the final volume of $1.0 \mathrm{~mL}$ (in mmol/L), of 2.5 pyruvic acid, 2.5 L-malate (Merck SA, Darmstadt, Germany), $90 \mathrm{NaCl}, 30 \mathrm{KCl}, 20 \mathrm{NaHEPES} \mathrm{pH} \mathrm{=} \mathrm{7.4,} 1.5$ Na-phosphate, 32 sucrose (Avantor Performance Materials, Gliwice, Poland), and $0.7-1.0 \mathrm{mg}$ of cell protein. After incubation, the cells were separated from the medium by centrifugation for $30 \mathrm{~s}$ at 10,000 rpm. These conditions provided stability of the acetyl-CoA level in the cells. For total acetyl-CoA content determination, $0.20 \mathrm{~mL}$ of cell suspension in incubation medium was centrifuged and the pellet was deproteinized with $0.20 \mathrm{~mL}$ of $4 \% \mathrm{HClO}_{4}$ (Avantor Performance Materials, Gliwice, Poland). Acetyl-CoA levels were estimated using the cycling method. Deproteinized extracts were put into a solution containing maleic anhydride (Merck SA, Darmstadt, Germany) in ethyl ether to remove CoA-SH for $2 \mathrm{~h}$. The cycling reaction was carried out in $0.10 \mathrm{~mL}$ of medium containing (in mmol/L) 1.9 acetyl phosphate, 1.2 oxaloacetate, $1.0 \mathrm{IU}$ phosphotransacetylase, and $0.12 \mathrm{IU}$ citrate synthase (Merck SA, Darmstadt, Germany) for $90 \mathrm{~min}$. The cycling reaction was stopped by heating the samples to $100{ }^{\circ} \mathrm{C}$ for $10 \mathrm{~min}$ and the citrate formed was determined [33,38]. The media for citrate measurement at the final volume of $0.70 \mathrm{~mL}$ consisted of (in mmol/L) 100 Tris $/ \mathrm{HCl}$ buffer $\mathrm{pH}=7.4,0.10 \mathrm{NADH}, 0.2 \mathrm{~J} . \mathrm{M}$. malic dehydrogenase, and $0.20 \mathrm{~mL}$ of tested sample. The reaction was initiated by the addition of 0.1 J.M. citrate lyase. The activity was expressed in mmols of oxidized NADH on the basis of absorbance ratio for $\mathrm{NADH}=6.22 \mathrm{~mol} / \mathrm{cm}$ at the wavelength $=340 \mathrm{~nm}$.

\subsection{Thiamine Pyrophosphate Assay}

For TPP assay, the cells were grown on 3-centimeter-diameter plates with or without cytotoxic factors, as described in Section 2.1. After $72 \mathrm{~h}$, media were withdrawn and cells that were attached to the plates were gently washed once with ice-cold PBS supplemented with $1 \mathrm{mmol} / \mathrm{L}$ EDTA to remove surface-bound metals. The collected cells were homogenized in $1 \mathrm{~mL}$ of ice cold $4 \%$ trichloroacetic acid. TPP was measured in supernatant by reverse-phase HPLC with an electrochemical detector [39].

\subsection{Protein Assay}

Protein level was measured using the Bradford method (1976) with human immunoglobulin as the standard.

\subsection{Zinc Assay}

Intracellular $\mathrm{Zn}$ level was measured in the cells cultured on 3-centimeter-diameter plates and treated as described in Section 2.1. After $72 \mathrm{~h}$, media were withdrawn and the cells that were attached to the plates were gently washed once with ice cold PBS supplemented with $1 \mathrm{mM}$ EDTA to remove surface-bound metals. Subsequently, $1.5 \mathrm{~mL}$ of ice cold $4 \% \mathrm{HClO}_{4}$ was added on the plate and incubated on ice for 1-2 min. Then, the cells were collected into ice cold plastic tubes. Protein precipitates were removed by centrifugation for $60 \mathrm{~s}$ at $5000 \mathrm{rpm}$. The supernatants were neutralized with $7.5 \mathrm{~N} \mathrm{~K}_{2} \mathrm{CO}_{3}$ to $\mathrm{pH}$ 6.0. Next, the neutralized supernatants were used for $\mathrm{Zn}$ assay with a modified fluorometric method with N-(6-methoxy-8-quinolyl)-p-toluenesulfonamide (TSQ) (ThermoFisher Scientific, UK). The measurement was conducted in a medium that contained $1.60 \mathrm{~mL}$ of $0.10 \mathrm{mmol} / \mathrm{L}$ Na-HEPES pH 7.4, $0.40 \mathrm{~mL}$ of neutralized supernatant, and $0.02 \mathrm{~mL}$ of TSQ in a 2-milliliter quartz cuvette. The analysis was conducted on a fluorescence spectrometer (LS-55, Perkin Elmer) with emission and excitation wavelengths equal to 335 and $495 \mathrm{~nm}$, respectively, against a blank reagent that was treated similarly.

To quantify analysis, the peak of emission was calculated from the calibration curve in the range $0.2-4$ nmols/sample of $\mathrm{ZnCl}_{2}$ standard solution treated similarly to the samples [40]. 


\subsection{Statistical Analyses}

Statistical analyses were carried out using GraphPad Prism 5 (GraphPad software, La Jolla, CA, USA). No sample calculation was performed. Data are presented as means \pm SEM or median \pm Whiskers: Min to Max from 3-6 independent cell culture preparations. The assessment of normality of the data was carried out using the Shapiro-Wilk normality test. Data analysis was carried out using the Kruskal-Wallis normality test. The two groups were compared using a non-parametric Mann-Whitney test, with $p<0.05$ being considered to be statistically significant. No test for outliers was used.

\section{Conclusions}

Although the development of medicine has made our lifespans longer, there is a higher risk of the progression of neurodegenerative disease. It is estimated that 35 million people suffer from Alzheimer's disease worldwide. Moreover, it is predicted that this number will triple by 2050. AD is also compounded by thiamine deficiency, especially among elderly people who are malnourished. There is no effective therapy against any neurodegenerative disease. Therefore, knowledge about the molecular mechanism of $\mathrm{AD}$ should help in the development of a successful therapy. The presented data indicate that astroglial cells are more resistant to thiamine deficiency and $\mathrm{Zn}$ excess than neuronal cells. This may be caused by similar levels of intracellular Zn accumulated in TD-C6, causing a much weaker inhibition of PDH, aconitase and ICDH activities, and acetyl-CoA levels than in neuronal TD-SN56 cells. Thanks to this, in a co-culture, astroglia may retain their ability to take up Zn excess and provide TPP to the neuronal vicinity. Thus, astroglia could prevent the inhibition of PDH and aconitase and ICDH-NADP activities and maintain the acetyl-CoA needed for neuronal viability. Therefore, therapeutic approaches that protect astrocytes against cytotoxic insults may ensure preservation against zinc overload in cholinergic neurons.

Author Contributions: Conceptualization, A.R.; methodology, S.G.-H.; software, A.R.; validation, A.J.-K. and M.Z.; formal analysis, A.S.; investigation, S.G.-H. and M.Z.; resources, A.R.; data curation, A.M.; writing-original draft preparation, A.R.; writing-review and editing, A.S.; visualization, M.Z.; supervision, A.R.; project administration, A.R. All authors have read and agreed to the published version of the manuscript.

Funding: Work was supported by the Ministry of Research and Higher Education-the Medical University of Gdańsk fund (ST-57 02-0057/07/248).

Institutional Review Board Statement: The study was conducted according to the guidelines of the Declaration of Helsinki, and approved by the Ethics Commission on Animal Experiments at the Medical University of Gdańsk (permission no. 27/2013).

Informed Consent Statement: Not applicable.

Data Availability Statement: The data that support the findings of this study are available from the corresponding author upon reasonable request.

Conflicts of Interest: The authors declare no conflict of interest.

\section{References}

1. Cunnane, S.; Nugent, S.; Roy, M.; Courchesne-Loyer, A.; Croteau, E.; Tremblay, S.; Castellano, A.; Pifferi, F.; Bocti Ch Paquet, N.; Begdouri, H.; et al. Brain fuel metabolism, aging, and Alzheimer's disease. Nutrition 2011, 27, 3-20. [CrossRef] [PubMed]

2. Szutowicz, A.; Bielarczyk, H.; Jankowska-Kulawy, A.; Pawełczyk, T.; Ronowska, A. Acetyl-CoA the key factor for survival or death of cholinergic neurons in course of neurodegenerative diseases. Neurochem. Res. 2013, 38, 1523-1542. [CrossRef] [PubMed]

3. Ronowska, A.; Szutowicz, A.; Bielarczyk, H.; Gul-Hinc, S.; Klimaszewska-Łata, J.; Dyś, A.; Zyśk, M.; Jankowska-Kulawy, A. The Regulatory Effects of Acetyl-CoA Distribution in the Healthy and Diseased Brain. Front. Cell Neurosci. 2018, 12, 169. [CrossRef] [PubMed]

4. Bielarczyk, H.; Jankowska, A.; Madziar, B.; Matecki, A.; Michno, A.; Szutowicz, A. Differential toxicity of nitric oxide, aluminium and amyloid beta peptide in SN56 cholinergic cells from mouse septum. Neurochem. Int. 2003, 42, 323-331. [CrossRef] 
5. Ronowska, A.; Gul-Hinc, S.; Michno, A.; Bizon-Zygmańska, D.; Zyśk, M.; Bielarczyk, H.; Szutowicz, A.; Gapys, B.; JankowskaKulawy, A. Aggravated effects of coexisting marginal thiamine deficits and zinc excess on SN56 neuronal cells. Nutr. Neurosci. 2019, 24, 432-442. [CrossRef]

6. Victor, M.; Adams, R.D.; Collins, G.H. The Wernicke-Korsakoff syndrome. A clinical and pathological study of 245 patients, 82 with post-mortem examinations. Contemp. Neurol. Ser. 1971, 7, 1-206. [PubMed]

7. Onozuka, M.; Nosaka, K. Steady-state kinetics and mutational studies of recombinant human thiamin pyrophosphokinase. J. Nutr. Sci. Vitaminol. 2003, 49, 156-162. [CrossRef] [PubMed]

8. Bubber, P.; Ke, Z.J.; Gibson, G. Tricarboxylic acid cycle enzymes following thiamine deficiency. Neurochem. Int. 2004, 45, 1021-1028. [CrossRef]

9. Thomson, A.D.; Cook, C.C.; Guerrini, I.; Sheedy, D.; Harper, C.; Marshall, E.J. Wernicke's encephalopathy revisited. Translation of the case history section of the original manuscript by Carl Wernicke "Lehrbuch der Gehirnkrankheiten fur Aerzte and Studirende" (1881) with a commentary. Alcohol Alcohol. 2008, 43, 174-179. [CrossRef] [PubMed]

10. Gibson, G.E.; Hirsch, J.A.; Fonzetti, P.; Jordan, B.D.; Cirio, R.T.; Elder, J. Vitamin B1 (thiamine) and dementia. Ann. N. Y. Acad. Sci. 2016, 1367, 21-30. [CrossRef]

11. Lavoie, J.; Butterworth, R.F. Reduced activities of thiamine-dependent enzymes in brains of alcoholics in the absence of Wernicke's encephalopathy. Alcohol. Clin. Exp. Res. 1995, 19, 1073-1077. [CrossRef]

12. Jankowska-Kulawy, A.; Bielarczyk, H.; Pawełczyk, T.; Wróblewska, M.; Szutowicz, A. Acetyl-CoA deficit in brain mitochondria in experimental thiamine deficiency encephalopathy. Neurochem. Int. 2010, 57, 851-856. [CrossRef]

13. Zyśk, M.; Bielarczyk, H.; Gul-Hinc, S.; Dyś, A.; Gapys, B.; Ronowska, A.; Sakowicz- Burkiewicz, M.; Szutowicz, A. Phenotypedependent interactions between N-acetyl-L-aspartate and acetyl-CoA in septal SN56 cholinergic cells exposed to an excess of zinc. J. Alzheimers Dis. 2017, 56, 1145-1158. [CrossRef] [PubMed]

14. Sensi, S.L.; Paoletti, P.; Bush, A.I.; Sekler, I. Zinc in the physiology and pathology of the CNS. Nat. Rev. Neurosci. 2009, 10, 780-791. [CrossRef]

15. Takeda, A.; Nakamura, M.; Fujii, H.; Tamano, H. Synaptic Zn(2+) homeostasis and its significance. Metallomics 2013, 5, 417-423. [CrossRef]

16. Ronowska, A.; Dyś, A.; Jankowska-Kulawy, A.; Klimaszewska-Łata, J.; Bielarczyk, H.; Romianowski, P.; Pawełczyk, T.; Szutowicz, A. Short-term effects of zinc on acetylcholine metabolism and viability of SN56 cholinergic neuroblastoma cells. Neurochem. Int. 2010, 56, 143-151. [CrossRef] [PubMed]

17. Ronowska, A.; Gul-Hinc, S.; Bielarczyk, H.; Pawełczyk, T.; Szutowicz, A. Effects of zinc on SN56 cholinergic neuroblastoma cells. J. Neurochem. 2007, 103, 972-983. [CrossRef] [PubMed]

18. Allen, N.J.; Barres, B.A. Neuroscience: Glia-More than just brain glue. Nature 2009, 457, 675-677. [CrossRef]

19. Li, B.; Xia, M.; Zorec, R.; Parpura, V.; Verkhratsky, A. Astrocytes in heavy metal neurotoxicity and neurodegeneration. Brain Res. 2021, 1752, 147234. [CrossRef] [PubMed]

20. Kalsbeek, M.J.; Mulder, L.; Yi, C.X. Microglia energy metabolism in metabolic disorder. Mol. Cell Endocrinol. 2016, 438, 27-35. [CrossRef]

21. Afadlal, S.; Labetoulle, R.; Hazell, A.S. Role of astrocytes in thiamine deficiency. Metab. Brain Dis. 2014, 29, 1061-1068. [CrossRef]

22. Bettendorff, L.; Sluse, F.; Goessens, G.; Wins, P.; Grisar, T. Thiamine deficiency-induced partial necrosis and mitochondrial uncoupling in neuroblastoma cells are rapidly reversed by addition of thiamine. J. Neurochem. 1995, 65, 2178-2184. [CrossRef] [PubMed]

23. Bizon-Zygmańska, D.; Jankowska-Kulawy, A.; Bielarczyk, H.; Pawełczyk, T.; Ronowska, A.; Marszałł, M.; Szutowicz, A. AcetylCoA metabolism in amprolium-evoked thiamine pyrophosphate deficits in cholinergic SN56 neuroblastoma cells. Neurochem. Int. 2011, 59, 208-216. [CrossRef] [PubMed]

24. Hertz, L.; Chen, Y.; Song, D. Astrocyte cultures mimicking brain astrocytes in geneexpression, signaling, metabolism and K(+) uptake and showing astrocytic geneexpression overlooked by immunohistochemistry and in Situ hybridization. Neurochem. Res. 2017, 42, 254-271. [CrossRef] [PubMed]

25. Mkrtchyan, G.; Graf, A.; Bettendorff, L.; Bunik, V. Cellular thiamine status is coupled to function of mitochondrial 2-oxoglutarate dehydrogenase. Neurochem. Int. 2016, 101, 66-77. [CrossRef] [PubMed]

26. Lonsdale, D. Thiamine and magnesium deficiencies: Keys to disease. Med. Hypotheses 2015, 84, 129-134. [CrossRef]

27. Bozym, R.A.; Chimienti, F.; Giblin, L.J.; Gross, G.W.; Korichneva, I.; Li, Y.; Libert, S.; Maret, W.; Parviz, M.; Frederickson, C.J.; et al. Free zinc ions outside a narrow concentration range are toxic to a variety of cells in vitro. Exp. Biol. Med. 2010, 235, 741-750. [CrossRef] [PubMed]

28. Moreira-Lobo, D.C.; Cruz, J.S.; Silva, F.R.; Ribeiro, F.M.; Kushmerick, C.; Oliveira, F.A. Thiamine deficiency increases Ca(2+) current and $\mathrm{Ca}(\mathrm{V}) 1.2 \mathrm{~L}$-type $\mathrm{Ca}(2+)$ channel levels in cerebellum granular neurons. Cell Mol. Neurobiol. 2017, 37, 453-460. [CrossRef]

29. Zyśk, M.; Gapys, B.; Ronowska, A.; Gul-Hinc, S.; Erlandsson, A.; Iwanicki, A.; Sakowicz-Burkiewicz, M.; Szutowicz, A.; Bielarczyk, H. Protective effects of voltage-gated calcium channel antagonists against zinc toxicity in SN56 neuroblastoma cholinergic cells. PLoS ONE 2018, 20, e0209363. [CrossRef]

30. De Benedictis, C.A.; Haffke, C.; Hagmeyer, S.; Sauer, A.K.; Grabrucker, A.M. Expression Analysis of Zinc Transporters in Nervous Tissue Cells Reveals Neuronal and Synaptic Localization of ZIP4. Int. J. Mol. Sci. 2021, 22, 4511. [CrossRef] 
31. Bélanger, M.; Allaman, I.; Magistretti, P.J. Brain energy metabolism: Focus on astrocyte-neuron metabolic cooperation. Cell Metab. 2011, 14, 724-738. [CrossRef] [PubMed]

32. Tian, Z.Y.; Wang, C.Y.; Wang, T.; Li, Y.C.; Wang, Z.Y. Glial S100A6 degrades $\beta$-amyloid aggregation through targeting competition with zinc ions. Aging Dis. 2019, 10, 756-769. [CrossRef]

33. Szutowicz, A.; Jankowska, A.; Blusztajn, J.K.; Tomaszewicz, M. Acetylcholine and acetyl-CoA metabolism in differentiating SN56 septal cell line. J. Neurosci. Res. 1999, 57, 131-136. [CrossRef]

34. Mosmann, T. Rapid colorimetric assay for cellular growth and survival: Application to proliferation and cytotoxicity assays. J. Immunol. Methods 1983, 65, 55-63. [CrossRef]

35. Szutowicz, A.; Stepien, M.; Piec, G. Determination of pyruvate dehydrogenase and acetyl-CoA synthetase activities using citrate synthase. Anal. Biochem. 1981, 115, 81-87. [CrossRef]

36. Villafranca, J. The mechanism of aconitase action: Evidence for an enzyme isomerization by studies of inhibition by tricarboxylic acids. J. Biol. Chem. 1974, 249, 6149. [CrossRef]

37. Plaut, G.W.; Aogaichi, T. Purification and properties of diphosphopyridine nuleotide-linked isocitrate dehydrogenase of mammalian liver. J. Biol. Chem. 1968, 243, 5572-5583. [CrossRef]

38. Szutowicz, A.; Bielarczyk, H. Elimination of CoASH interference from acetyl-CoA cycling assay by maleic anhydride. Anal. Biochem. 1987, 164, 292-296. [CrossRef]

39. Lebiedzińska, A.; Marszałł, M.L.; Kuta, J.; Szefer, P. Reversed-phase high-performance liquid chromatography method with coulometric electrochemical and ultraviolet detection for the quantification of vitamins $\mathrm{B}(1)$ (thiamine), $\mathrm{B}(6)$ (pyridoxamine, pyridoxal and pyridoxine) and B(12) in animal and plant foods. J. Chromatogr. A 2007, 1173, 71-80. [CrossRef] [PubMed]

40. Chen, C.J.; Liao, S.L. Neurotrophic and neurotoxic effects of zinc on neonatal cortical neurons. Neurochem. Int. 2003, 42, 471-479. [CrossRef] 